\title{
Use of Landsat Imagery to Estimate Ground-Water Pumpage for Irrigation on the Columbia Plateau in Eastern Washington, 1985
}

By Peter Van Metre and Paul Seevers

U.S. GEOLOGICAL SURVEY

Water-Resources Investigations Report 89-4157

Prepared in cooperation with the

STATE OF WASHINGTON DEPARTMENT OF ECOLOGY 


\section{DEPARTMENT OF THE INTERIOR}

\section{MANUEL LUJAN, JR., Secretary}

\section{U.S. GEOLOGICAL SURVEY}

Dallas L. Peck, Director

Cover: Landsat TM image over Pasco, Washington. Circles are center pivot irrigation systems and are approximately one-half mile in diameter. Rivers are the Columbia River on the left and the Snake River on the right. Image courtesy of EROS Data Center, Sioux Falls, South Dakota.

For additional information write to:

\section{District Chief}

U.S. Geological Survey

1201 Pacific Avenue, Suite 600

Tacoma, Washington $98402-4384$
Copies of this report may be purchased from:

U.S. Geological Survey Books and Open-File Reports Section Federal Center, Box 25425

Denver, Colorado 80225 


\section{CONTENTS}

ABSTRACT --

INTRODUCTION -

Purpose and scope

Description of the study area -

Acknowledgments - -

LANDSAT ANALYSIS - -

Comparison of four Landsat multispectral scanner approaches - -

Classification using Landsat multispectral scanner data -...-

Classification using Landsat thematic mapper data - -

DEVELOPMENT OF A GROUND-WATER-USE MODEL

Collection and calculation of pumpage data at sample sites -

Water-level and line-pressure measurement - -

Statistical analysis ---

CALCULATION OF PUMPAGE -

Accuracy -

Discussion -

SUMMARY -

SELECTED REFERENCES - - 38

\section{ILLUSTRATIONS}

FIGURE 1. Map showing location of study area and Landsat images -..-- 3

2. Map showing location of areas potentially irrigated by ground water and location of ground-truth sites - -.-.-.- 6

3. Map showing precipitation by quarter-township for the 1985 water year, and location of the three example areas shown in figure 4 -

4. Map showing results of Landsat multispectral scanner classification for three example areas, and available ground truth

5. Map showing parts of the study area analyzed using Landsat thematic mapper data - - -

6. Map showing results of Landsat thematic mapper classification for three example areas, and available ground truth

7. Map showing location of water-application-rate sample sites and acreage for small grains, by quarter-township, for 1985 


\section{ILLUSTRATIONS--Continued}

FIGURE 8. Map showing location of water-application-rate sample sites and acreage for corn,

potatoes, and alfalfa, by quarter-township, for 1985

9. Histograms of water-application rates for (a) sampled crops, (b) three crop categories

10. Residual of regression-predicted water-application rates for sample sites

11. Map showing pumpage, by quarter-township, for 1985 33

12. Graphs showing summary of irrigated acreage and water use, by county, for 1985

\section{TABLES}

TABLE 1. Results of four Landsat multispectral scanner approaches for the Franklin

County test area

2. Ground-truth assessments for multispectral scanner (MSS) and thematic mapper

(TM) analysis

3. Water-application-rate pumpage samples by county and crop category

4. Method of assigning values to class variables for regression analysis

5. Ground-water pumpage, irrigated acreage, and application rates for 1985

6. Ground-water pumpage and irrigated acreage by county

7. Observed and predicted application rates, acres, and pumpage for 28 test sites 36

\section{CONVERSION FACTORS}

For the convenience of readers who may prefer to use metric units rather than the inch-pound units used in this report, values may be converted by using the following factors:

Multiply inch-pound unit

inch (in.)

foot (ft)

mile (mi)

acre

square mile $\left(\mathrm{mi}^{2}\right)$ by

25.4

0.0254

0.3048

1.609

4,047.

2.590 to obtain metric unit

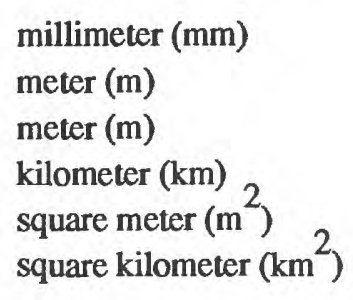

Sea level: In this report "sea level" refers to the National Geodetic Vertical Datum of 1929 (NGVD of 1929)--a geodetic datum derived from a general adjustment of the first-order level nets of both the United States and Canada, formerly called Sea Level Datum of 1929.

$$
\text { degree Fahrenheit }\left({ }^{\circ} \mathrm{F}\right) \quad{ }^{\circ} \mathrm{C}=5 / 9\left({ }^{\circ} \mathrm{F}-32\right) \quad \text { degree Celsius }\left({ }^{\circ} \mathrm{C}\right)
$$




\title{
Use Of Landsat Imagery To Estimate Ground-Water Pumpage For Irrigation On The Columbia Plateau In Eastern Washington, 1985
}

\author{
By Peter Van Metre and Paul Seevers
}

\begin{abstract}
A method for estimating ground-water pumpage for irrigation was developed for the Columbia Plateau in eastern Washington. The method combines water-application rates estimated from pumpage data with acreage of irrigated crops that was mapped by using Landsat imagery. The study area consisted of Grant, Lincoln, Adams, and Franklin Counties, an area of approximately 8,900 square miles, and accounts for approximately three-fourths of the ground-water pumpage in the Columbia Plateau in eastern Washington.

Data from two passes of Landsat's multispectral scanner were analyzed by using a spectral band ratioing procedure to map irrigated crops for the study area. Data from one pass of Landsat's thematic mapper, covering approximately two-thirds of the study area, also were analyzed for determining irrigated crops in the area resulting in a 6-percent improvement in accuracy over the multispectral scanner analysis.

A total of 576 annual water-application rates associated with particular crops, for the 1982 through 1985 seasons, were calculated. A regression equation was developed for estimating annual water-application rates as a function of crop type, annual precipitation, irrigation system type, and available water capacity of the soil. Crops were grouped into three water-use categories: (1) small grains, primarily wheat and barley; (2) high water-use crops consisting of corn, alfalfa, and potatoes; and (3) miscellaneous vegetable and row crops. Annual water-application rates, expressed as a depth of water, then were multiplied by irrigated area determined by Landsat to estimate a volume of water pumped for irrigation for 1985--620,000 acre-feet. An assessment of accuracy for estimating pumpage for 28 of the sites showed that total predicted pumpage was within 4 percent of the total observed pumpage.
\end{abstract}




\section{INTRODUCTION}

The Columbia Plateau in eastern Washington, with fertile soils and a semiarid climate, has undergone extensive development of irrigated agriculture since the 1950's, and today, irrigation is the primary use of ground water. To assess adequately the ground-water resources in the region, the U.S. Geological Survey, in cooperation with the State of Washington Department of Ecology, did a study to determine the quantity of water pumped and the distribution and rates of application of that water.

The approach adopted for this study had three phases: (1) mapping irrigated lands and, if possible, identifying crops for the ground-water-irrigated portions of the study area for the 1985 growing season using Landsat imagery; (2) estimating annual water-application rates for irrigated crops by using pumpage data (a regression model); and (3) calculating total 1985 pumpage for irrigation by multiplying estimated annual waterapplication rates by acreage of irrigated crops mapped using Landsat imagery.

\section{Purpose and Scope}

This report presents a method for estimating ground-water pumpage for irrigation on the Columbia Plateau in eastern Washington. The method combines annual water-application rates estimated from pumpage data with acreage of irrigated crops that was mapped using Landsat imagery. The area chosen for the study includes Grant, Lincoln, Adams, and Franklin Counties (fig. 1). Pumpage data were obtained from private owners and were collected by U.S. Geological Survey personnel for the 1982 through 1985 growing seasons over the four-county area.

Field mapping of irrigated crops for use in the Landsat analysis (such data are known as ground truth) was done for the 1984 and 1985 growing season by personnel with the State of Washington Department of Ecology for the four-county area and parts of Benton and Walla Walla Counties. Landsat mapping, which consisted of data from both the multispectral scanner (MSS) and the thematic mapper (TM), of ground-water irrigated crops was done for the 1985 growing season. Four different data manipulation approaches using MSS data were compared, and the best of those approaches was compared with TM analysis.

Ground-water pumpage for irrigation was estimated for 1985 by using the Landsat mapping results and a regression equation developed from pumpage data. The regression equation was used to estimate the annual depth of water applied to irrigated lands on the basis of crop type, available water capacity of the soil, annual precipitation, and irrigation system type; an assessment of accuracy of the estimates also was made. 


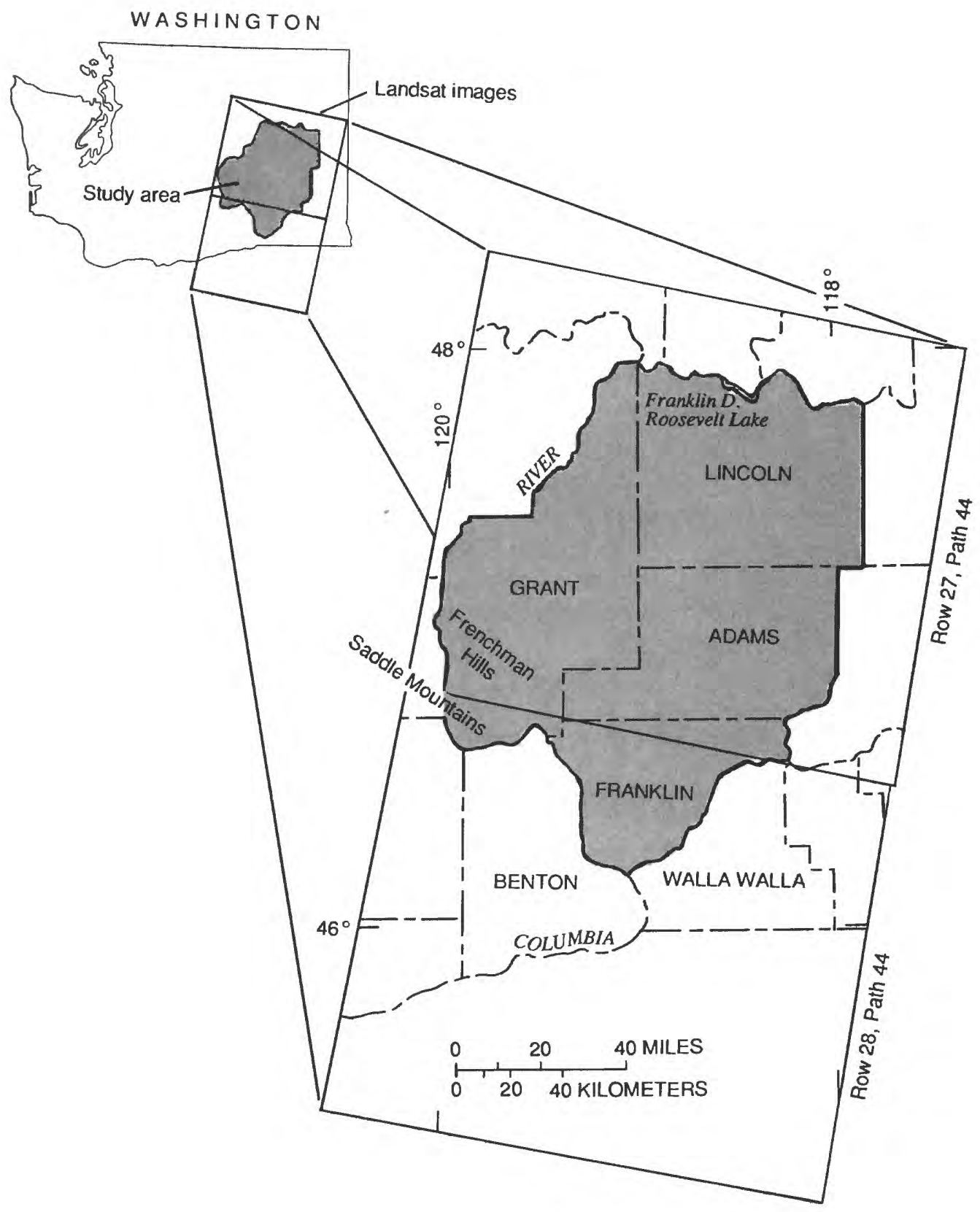

Figure 1.--Location of study area and Landsat images. 


\section{Description of the Study Area}

The study area consists of Grant, Lincoln, Adams, and Franklin Counties in eastern Washington (fig. 1), an area of approximately $8,900 \mathrm{mi}^{2}$ (square miles). Elevation ranges from approximately 300 feet above sea level in southern Franklin County to approximately 2,500 feet in central Lincoln County. The topography is flat to gently rolling with two large east-west trending anticlines, the Saddle Mountains and the Frenchman Hills, in Grant County and numerous coulees that extend to parts of all four counties.

Average annual precipitation generally ranges from 7 inches in western Grant County to 17 inches in northeastern Lincoln County (Donaldson, 1979; Phillips, 1965). Summer high temperatures commonly exceed 90 degrees Fahrenheit and occasionally 100 degrees Fahrenheit. Low precipitation and hot summers result in an arid to semiarid environment over most of the study area; there are few perennial streams. Native vegetation consists mostly of sagebrush and grasslands.

The predominant economic activity for the area is agriculture and its associated services. In 1982 there were $1,220 \mathrm{mi}^{2}$ of irrigated croplands in the four counties, of which approximately 70 percent was irrigated by surface water and 30 percent by ground water. The major source of surface water is the Columbia Basin Irrigation Project, drawing Columbia River water from Franklin Delano Roosevelt Lake and distributing it across the plateau through a system of canals. About three-fourths of the ground-water pumpage in the Columbia Plateau in eastern Washington is from the study area (Cline and Knadle, 1990). Ground-water levels have risen in areas of surface-water irrigation and declined locally in areas of ground-water irrigation.

\section{Acknowledgments}

We gratefully acknowledge the many farmers and landowners of eastern Washington who allowed us to monitor pumpage at their wells and who in some cases made their pumpage data available to us. We are also grateful to Daniel Wies, James Lyerla, William Myers, and others with the State of Washington Department of Ecology for collecting the crop ground truth essential to the Landsat mapping efforts. 


\section{LANDSAT ANALYSIS}

During the planning stages of this project, a multidate Landsat MSS data analysis was selected as the most promising approach to use for recognition of irrigated lands and identification of crops for the study area (Lo and others, 1986). In addition, mapping of crops using one pass of TM data was identified as a promising alternative to the MSS approach. Irrigated acres by crop type are needed in conjunction with estimated annual water-application rates to yield volume of water pumped. The digital Landsat analysis was done by the EROS Data Center, Sioux Falls, South Dakota, in cooperation with the U.S. Geological Survey.

Landsat sensors measure the intensity or brightness of reflectance (and radiation) at several discrete ranges in the electromagnetic spectrum. The ranges, referred to as spectral bands, are in the visible and nearinfrared portions of the spectrum except for TM band 6, which is in the thermal infrared range. There are four bands measured by the MSS sensor at a nominal resolution of approximately 260 feet. There are seven bands measured by the TM sensor at a nominal resolution of approximately 98 feet (except for TM band 6, which has a resolution of approximately 400 feet). These data are transmitted digitally to Earth and made available as digital data for computer analysis or used to generate pictures for visual analysis.

Two Landsat images are required to cover the four-county study area (fig. 1). Two passes (May 21 and August 25, 1985) of MSS data were selected for analysis, for a total of four images. These images showed different crop growth stages of the same growing season and were cloud free. The timing of the data collection was designed to take advantage of maximum spectral differences between major crop types; this aided in differentiating between crop types.

The selected data were processed by the Data Production and Distribution Branch of the EROS Data Center prior to being classified. Classification of Landsat data refers to the process of analyzing these data, either visually or by computer, to identify and map areas or land-use types of interest. For this study, the land-use types of interest were ground-water-irrigated crops. Parts of the images that were not of interest were eliminated from further analysis to focus the classification procedure on ground-water-irrigated lands. Boundaries between the surface-water-irrigated lands and the ground-water-irrigated lands were delineated on maps (scale 1:100,000). These boundaries were digitized and combined with a map consisting of a radius around irrigation wells determined to be active during a study of water use in the Columbia Plateau (D. R. Cline, U.S. Geological Survey, oral commun., 1986). The resulting digital map (see fig. 2) was overlaid with the Landsat images, and all areas not falling within areas designated as potential locations of ground-water irrigation were eliminated from further consideration.

Approximately 600 irrigated fields, covering the geographic range and crop diversity of the study area, were mapped by State of Washington Department of Ecology personnel. In a Landsat analysis, these data are referred to as ground truth. Points identifying the centers of the ground-truth sites were digitized so that they could be overlaid with the classified Landsat image (the digital map resulting from a Landsat classification) to assess the accuracy of identifying crops. Locations of crop ground-truth sites and the map used to delineate ground-water-irrigated areas are shown in figure 2. 


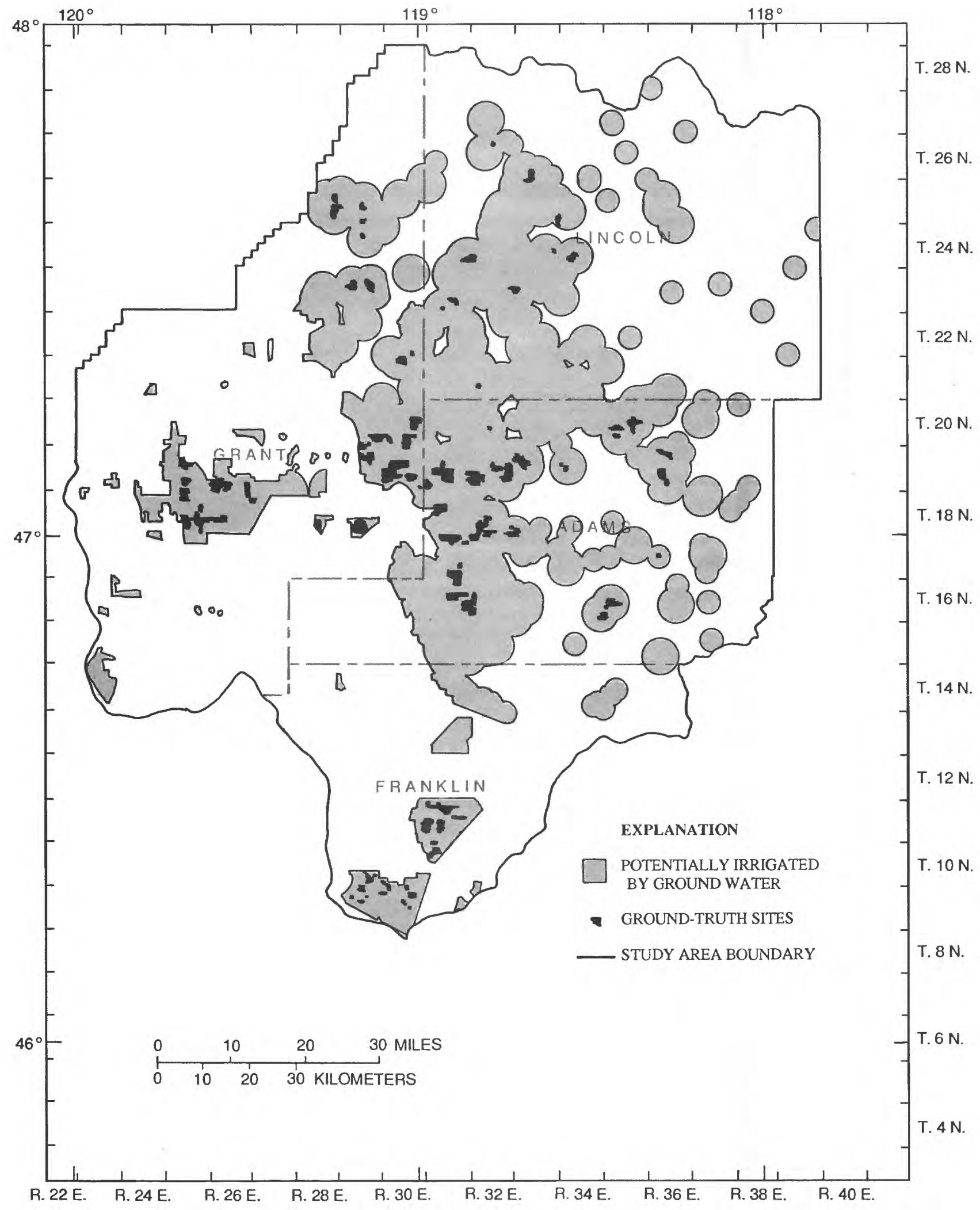

Figure 2.--Location of areas potentially irrigated by ground water and location of ground-truth sites. 
In each Landsat classification approach used in this study, the following basic steps were used.

1. A systematic sample of spectral band values for pixels was taken from the image being analyzed. (A pixel is a picture element and is a single gridded data value from a Landsat image.)

2. An unsupervised clustering (allowing the computer to group or 'cluster' data based on similar spectral response) then was applied to the systematic sample. The clustering algorithm groups the data by similar spectral response and develops a statistics file to describe each of those clusters. The number of clusters identified is controlled by the analyst. In each MSS classification approach tested, the number of clusters resulting from the processing of the systematic sample was less than the limit indicated as a parameter in the algorithm, and was approximately 30 .

3. Each pixel of the full image then was assigned to one of the classes developed by the clustering algorithm using a maximum likelihood classifier. This was accomplished by comparing the spectral band values for each pixel with the statistics file describing the classes. The result was an image with approximately 30 spectral classes.

4. That image then was displayed on a video-display terminal; classes were compared with ground-truth data and were assigned to land-use categories. The result was a classified Landsat image.

The variation within a single field growing one crop and between multiple fields growing the same crop is frequent enough to result in several identifiable spectral classes associated with a single crop. Those variations are the result of differences in agricultural practices, soil types, and precipitation. Grouping of the spectral classes for each MSS approach resulted in only three consistently separable land-use categories within the irrigated croplands. Those land-use categories are (1) small grains (wheat and barley), (2) alfalfa, and (3) corn and potatoes. All nonirrigated lands were grouped into a single, fourth category. Assuming that the ground-truth sample data are representative of ground-water-irrigated crops in the study area, wheat, barley, corn, potatoes, and alfalfa account for about 90 percent of the irrigated crops grown.

\section{Comparison of Four Landsat Multispectral Scanner Approaches}

Prior to classification of the full study area, four MSS classification approaches were compared for a 500-x-500-pixel subset of the study area in south-central Franklin County to determine a most effective approach. Two criteria, accuracy and the greatest reduction of data required for the analysis, were used to decide which approach was most effective. The four approaches were (1) an analysis using all eight spectral bands from the two dates of MSS data (Bauer and others, 1979); (2) a principal-components analysis (Abotteen, 1977); (3) a spectral band ratio approach resulting in two bands, and (4) a spectral band ratio approach resulting in three bands (Zhicheng, 1984). Unsupervised clustering was used in each approach for this study. Classification results then were compared with ground-truth data to assess accuracy. Accuracy, computed as the number of fields identified correctly, divided by the total number of fields, times 100 , was computed by crop type and by crop water-use category. Accuracy results are listed in table 1. 
TABLE 1.--Results of four Landsat multispectral scanner approaches

for the Franklin County test area

\begin{tabular}{|c|c|c|c|c|}
\hline \multirow[b]{2}{*}{$\begin{array}{l}\text { Analysis } \\
\text { approach }\end{array}$} & cent ident & s correct & ared to groun & ruth \\
\hline & $\begin{array}{l}\text { By } \\
\text { crop type }\end{array}$ & $\begin{array}{l}\text { By } \\
\text { water-use } \\
\text { category }\end{array}$ & $\begin{array}{c}\text { For } \\
\text { small grains }\end{array}$ & $\begin{array}{c}\text { For high } \\
\text { water-use } \\
\text { crops }\end{array}$ \\
\hline Eight-Band & 78.8 & 91.2 & 73.7 & 94.7 \\
\hline $\begin{array}{l}\text { Principal } \\
\text { component }\end{array}$ & 62.8 & 75.9 & 73.7 & 78.7 \\
\hline $\begin{array}{l}\text { Three-band } \\
\text { ratio }\end{array}$ & 84.1 & 91.2 & 94.7 & 90.4 \\
\hline $\begin{array}{l}\text { Two-band } \\
\text { ratio }\end{array}$ & 76.6 & 89.2 & 100 & 87.0 \\
\hline
\end{tabular}

Comparison of the classification results from each approach was made with the original image and with the ground-truth data available for that area. Equal or improved overall accuracy in identifying crops was obtained with the ratio approach that resulted in three bands. In addition, the amount of data required was reduced substantially by that approach, from the original eight bands to three. Therefore, the three-band ratio approach was selected for use on the full study area.

The preferred approach used a biomass transformation (Lo and others, 1986) known as band ratioing. Band ratioing enhances or magnifies differences between the reflectance values of the visible red band (band 2) and the near-infrared band (band 4). Vegetation will absorb radiation in the visible red band and reflect radiation in the near-infrared band. As the vigor of growth of vegetation increases, band 2 values decrease and band 4 values increase. Ratioing these two bands has the effect of emphasizing the relative greenness of the landcover classes of interest. Reflectance values for band 4 were divided by reflectance values for band 2 for each of the two Landsat passes used - May 21 and August 25, 1985. The resulting values were transformed linearly to values from 0 to 127, the same range of brightness values recorded by the Landsat sensors for each band. The band 4/band 2 ratio from the May image then was divided by the band 4/band 2 ratio from the August image and linearly transformed to create a third band that enhances the temporal contrast between row crops and small grains. The three bands were combined and classified as a single image.

\section{Classification Using Landsat Multispectral Scanner Data}

To classify the study area, spectral band ratios for the preferred approach were generated, and a 5 percent systematic sample of those values was taken. Unsupervised clustering produced 29 spectral classes to which pixels were assigned. Those classes were compared with ground truth and assigned to one of the four landuse categories: (1) small grains, (2) alfalfa, (3) corn and potatoes, and (4) nonirrigated lands. 
A postclassification editing procedure called nominal filtering was applied that eliminated some small areas of misclassification. If a pixel or group of pixels comprising 3 acres or less existed as an island surrounded by other classes, it was reassigned to one of the surrounding classes. This was particularly helpful in eliminating anomalies such as wet and dry spots in fields, small wetlands, confusion in urban areas, and border pixels around fields.

The classified image was converted from a raster (grid based) system to a vector (lines delineating areas or polygons) system using ARC/INFO . ARC/INFO is the combination of a relational data base management system (INFO) and a digital mapping system (ARC). This program has been used by the U.S. Geological Survey to develop data bases for geographic information systems.

Further editing of the classified image was done in ARC/INFO. Numerous small polygons above the 3-acre limit used in nominal filtering remained in the image. It was decided that polygons (irrigated fields) smaller than 7 acres were not of interest. An ARC/INFO program was used to assign those polygons to the adjacent polygon containing the longest common boundary with them. Editing also was done to remove large areas of wetlands and urban development in central Grant County and southern Franklin County, some of which had been classified as irrigated lands.

A visual comparison of plots of the classified image with ground truth and band 2 Landsat images from July 9,1985 , indicated considerable error in the separation of dryland from irrigated wheat, particularly in areas of higher precipitation in Lincoln and eastern Adams Counties. Figure 3 shows precipitation by quarter-township for the 1985 water year as interpolated by computer program from surrounding weather stations. Three example areas are outlined in figure 3, and classified results of those three areas are shown in figure 4, along with areas of available ground truth. An accuracy assessment by area is listed for each of the three areas. Apparently, the accuracy of the MSS approach used here declines dramatically in the northern and eastern parts of the study area.

Small grains account for more than half of all irrigated crops in the study area; therefore, correctly identifying them is important. The accuracy of the MSS classification for identifying crops in the low wateruse crop category, primarily small grains and peas, was 65 percent correct (crop water-use categories are described in the section "Statistical Analysis"). Most of the error in identifying low water-use crops was caused by misidentification of nonirrigated small grains. If the area analyzed is void of nonirrigated crops (all crops grown are irrigated), or if irrigated-field boundaries are mapped digitally and used to restrict the classification to irrigated lands only, then the Landsat data are relied on only to distinguish crop types, not to separate irrigated from nonirrigated fields growing the same crop. Had such digital field-boundaries data sets been available, a regrouping of classes and an accuracy assessment indicated that an accuracy of correctly identifying irrigated small grains of 91 percent would have resulted.

In summary, the MSS approach applied in this study appears to be suitable for mapping irrigated row crops, irrigated small grains, and nonagricultural lands, but unsuitable for distinguishing between irrigated and nonirrigated small grains. It is possible that the accuracy of separating irrigated and nonirrigated small grains could be improved by adding a third date of MSS data or changing the timing of the first date to late June, when moisture differences between irrigated and nonirrigated fields are usually greatest.

${ }^{1}$ Use of brand names in this report is for identification purposes only and does not constitute endorsement by the U.S. Geological Survey. 


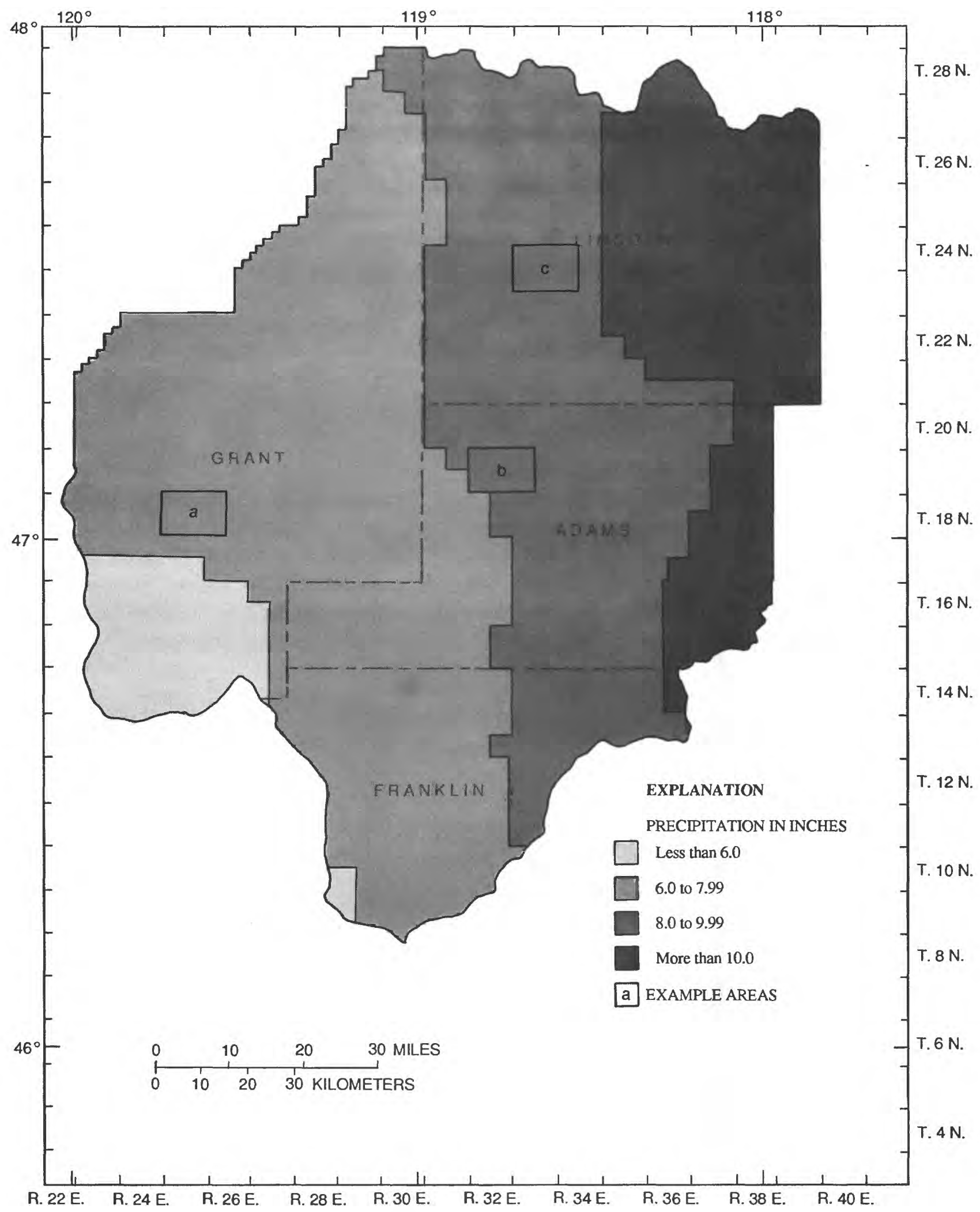

Figure 3.--Precipitation by quarter-township for the 1985 water year, and location of the three example areas shown in figure 4. 


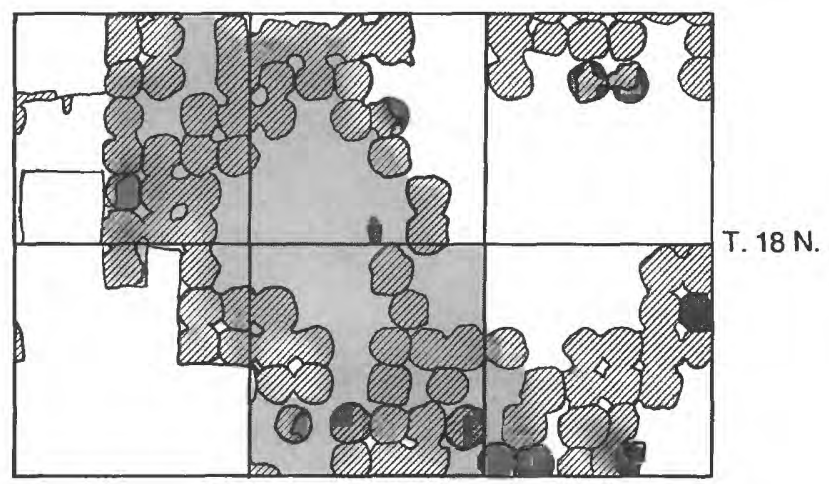

R. $25 \mathrm{E}$.

R. $26 \mathrm{E}$.

Example area a. Greater than 90 percent correct. by area.

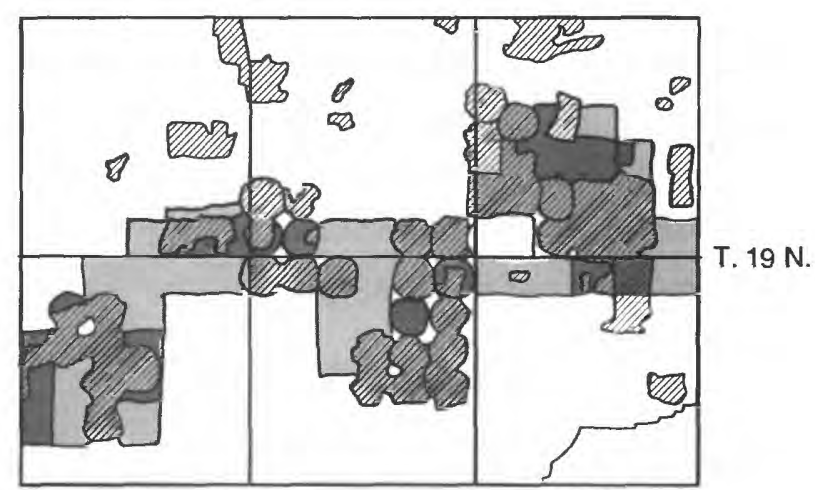

R. $32 \mathrm{E}$.

R. $33 \mathrm{E}$.
EXPLANATION

CORRECTLY IDENTIFIED BY

LANDSAT AS IRRIGATED LAND

CORRECTLY IDENTIFIED BY

LANDSAT AS NONIRRIGATED LAND

INCORRECTLY IDENTIFIED BY

LANDSAT AS IRRIGATED LAND

INCORRECTLY IDENTIFIED BY

LANDSAT AS NONIRRIGATED LAND

IDENTIFIED AS IRRIGATED, NO

GROUND TRUTH AVAILABLE

IDENTIFIED AS NONIRRIGATED, NO

GROUND TRUTH AVAILABLE

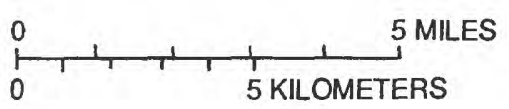

Example area b. Approximately 80 percent correct, by area.

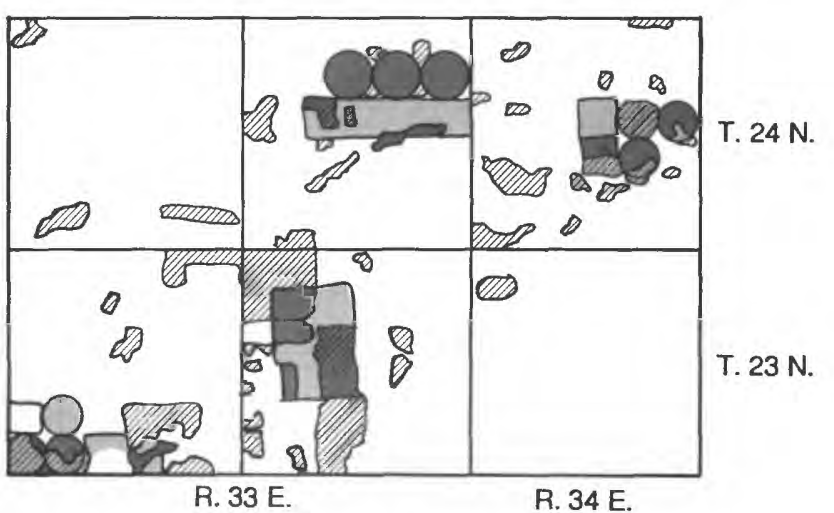

Example area c. Approximately 50 percent correct, by area.

Figure 4.--Results of Landsat multispectral scanner classification for three example areas, and available ground truth. See figure 3 for location of example areas in study area. 


\section{Classification Using Landsat Thematic Mapper Data}

Because TM data have higher spectral and spatial resolution than MSS data, crops were classified using TM data and the results compared with the MSS classification results. One image of TM data from June 22, 1985 , covering the northern two-thirds of the study area, was selected.

TM bands 3, 4, and 5 were chosen for classification. Initially, two test areas were analyzed, one in central Grant County and one in central and western Adams County. The classification procedure was similar to that used for the MSS data. The U.S. Bureau of Reclamation provided 283 ground-truth data points for the test area in central Grant County. The percentage of fields identified correctly using TM was 71 percent by crop type and was 94 percent by crop water-use category (crop water-use categories are discussed in the section "Statistical Analysis").

Another step in the classification procedure was added for the Adams County test area. Of the 36 classes determined initially, 13 were primarily irrigated lands, and 23 were primarily nonirrigated lands. It was felt that more distinctions could be made between various irrigated crops than 13 classes could define. The area encompassed by those 13 classes was retained and then classified again. This second classification procedure determined 36 classes within the irrigated lands. Identifiable crops included wheat, corn, potatoes, peas, and safflower. The percentage of correctly identified crops, when compared with 178 ground-truth data points, was 71 percent by crop type and 85 percent by water-use category.

Because the TM classification was more accurate than the MSS classification, particularly distinguishing between dryland and irrigated small grains, TM data were used to analyze most of the northern part of the study area (fig. 5). Results from the MSS analysis were replaced with TM results wherever they coincided. For the area where MSS and TM analyses coincided, the TM results were 6 percent more accurate than MSS by water-use category. The second classification procedure used for the Adams County test area was found to be of value only in areas where a relatively large diversity of crops was being grown, including nonirrigated small grains. Areas where that procedure was applied are indicated on figure 5.

TM classification results for irrigated and nonirrigated crops are shown in figure 6 for the same three areas for which MSS results were shown in figure 4. Results of accuracy assessments by crop type, by water-use category, and by irrigated compared with nonirrigated lands are given in table 2. Results are shown for classifications using MSS, MSS coincidental with the area analyzed using TM, TM, and the combined results for the study area.

TABLE 2.--Ground-truth assessments for multispectral scanner (MSS) and thematic mapper (TM) analysts

\begin{tabular}{|c|c|c|c|c|c|c|}
\hline Area & $\begin{array}{c}\text { Data } \\
\text { source }\end{array}$ & $\begin{array}{c}\text { By } \\
\text { crop type }\end{array}$ & $\begin{array}{l}\text { Bt determin } \\
\text { By } \\
\text { water-uae } \\
\text { catesory }\end{array}$ & $\begin{array}{c}\text { tion as correc } \\
\text { For } \\
\text { amall grains }\end{array}$ & $\begin{array}{l}\text { For high } \\
\text { water-uae } \\
\text { crops }\end{array}$ & $\begin{array}{c}\text { By 1rrigated } \\
\text { compared with } \\
\text { nonirrigated land }\end{array}$ \\
\hline $\begin{array}{l}\text { Total study } \\
\text { area }\end{array}$ & MSS & 66.4 & 72.1 & 65.1 & 78.1 & 80.7 \\
\hline TM area & MSS & 67.9 & 71.0 & 64.8 & 82.4 & 79.7 \\
\hline IM area & TM & 64.8 & 77.2 & 84.5 & 58.8 & 85.0 \\
\hline $\begin{array}{l}\text { Total study } \\
\text { area }\end{array}$ & $\begin{array}{l}\text { TM and } \\
\text { MSS }\end{array}$ & 64.5 & 75.0 & 81.9 & 61.9 & 83.5 \\
\hline
\end{tabular}




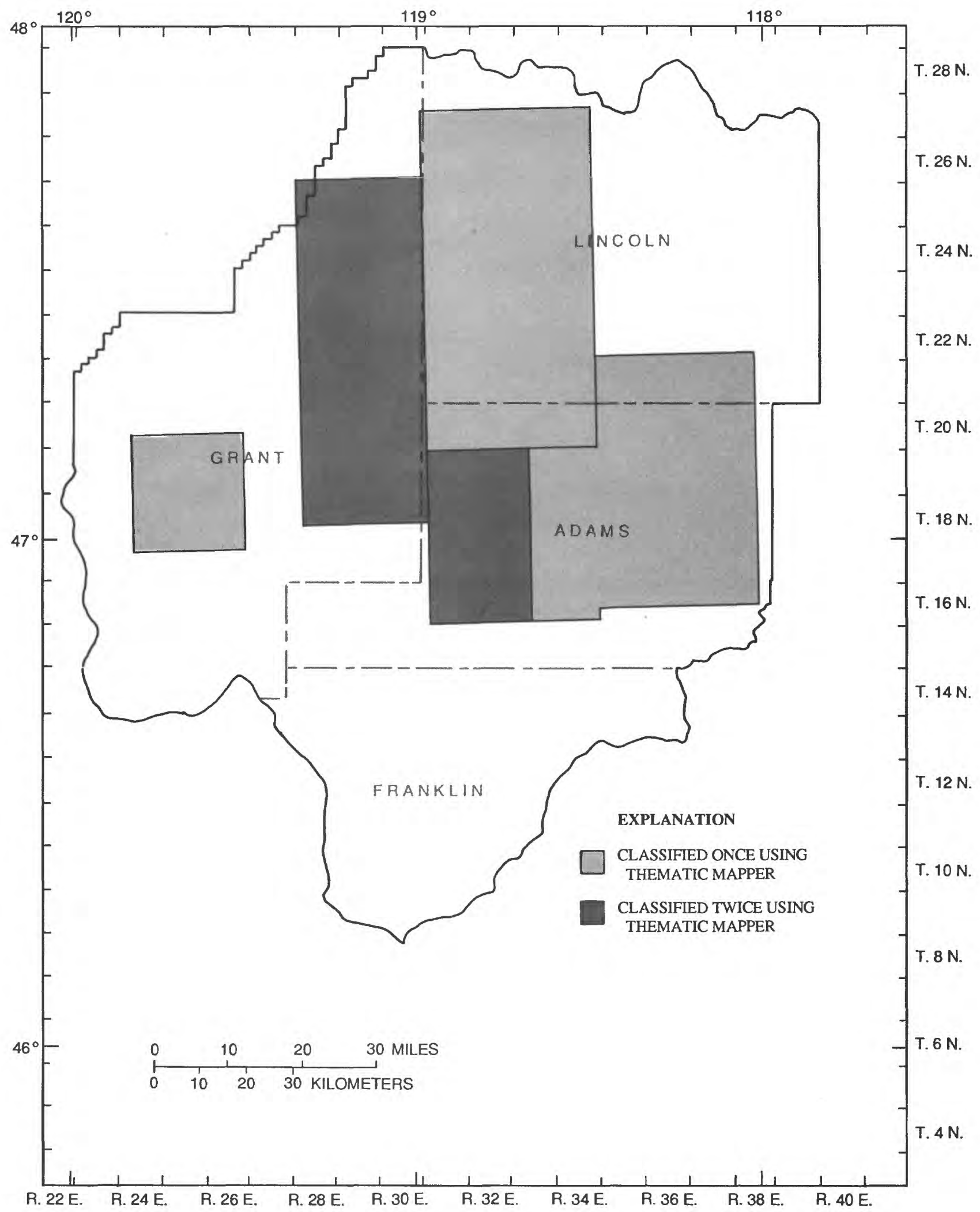

Figure 5.--Parts of the study area analyzed using Landsat thematic mapper data. 


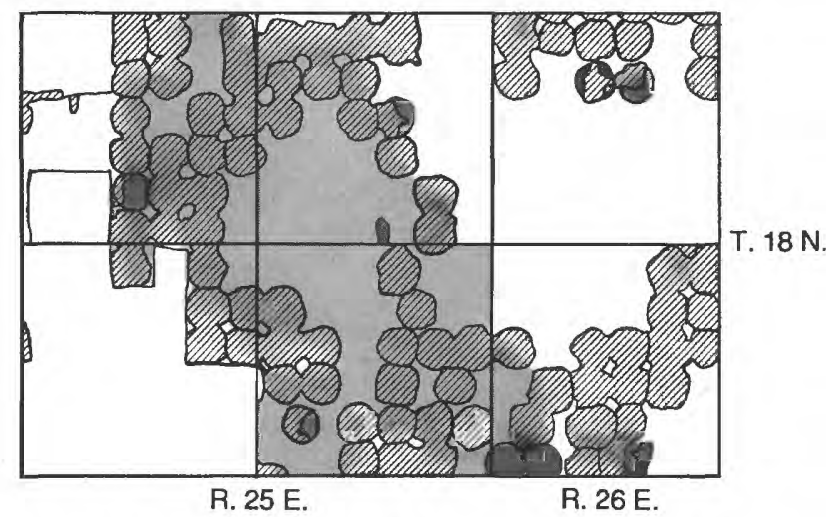

Example area a. Approximately 94 percent correct, by area.
EXPLANATION

CORRECTLY IDENTIFIED BY

LANDSAT AS IRRIGATED LAND

CORRECTLY IDENTIFIED BY

LANDSAT AS NONIRRIGATED LAND

INCORRECTLY IDENTIFIED BY

LANDSAT AS IRRIGATED LAND

INCORRECTLY IDENTIFIED BY LANDSAT AS NONIRRIGATED LAND

IDENTIFIED AS IRRIGATED, NO GROUND TRUTH AVAILABLE

IDENTIFIED AS NONIRRIGATED, NO GROUND TRUTH AVAILABLE
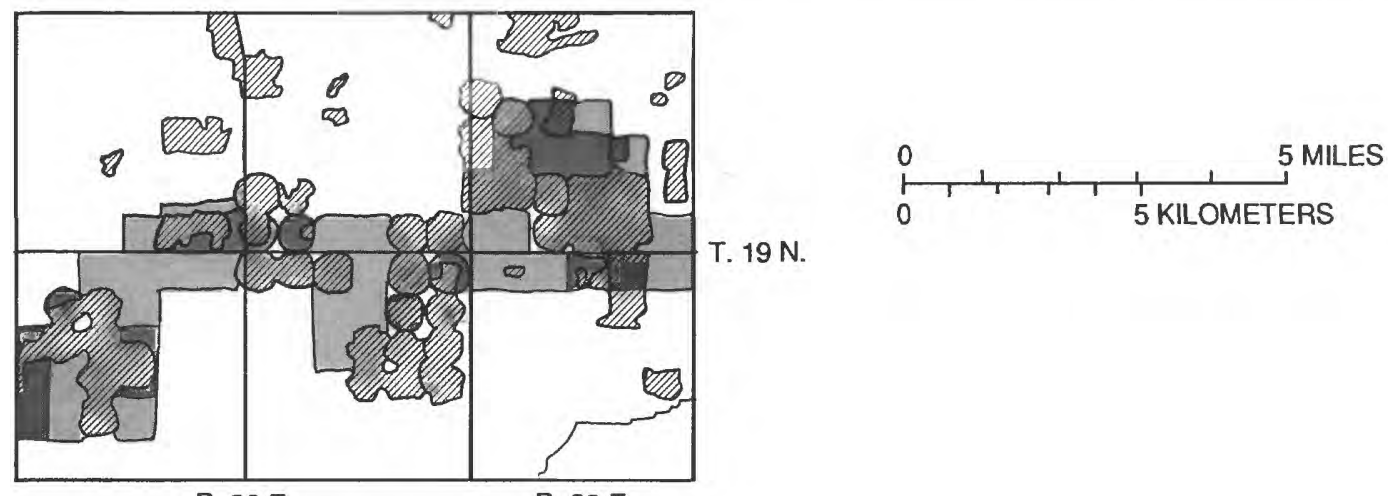

R. $32 \mathrm{E}$.

R. $33 \mathrm{E}$.

Example area b. Approximately 80 percent correct, by area.

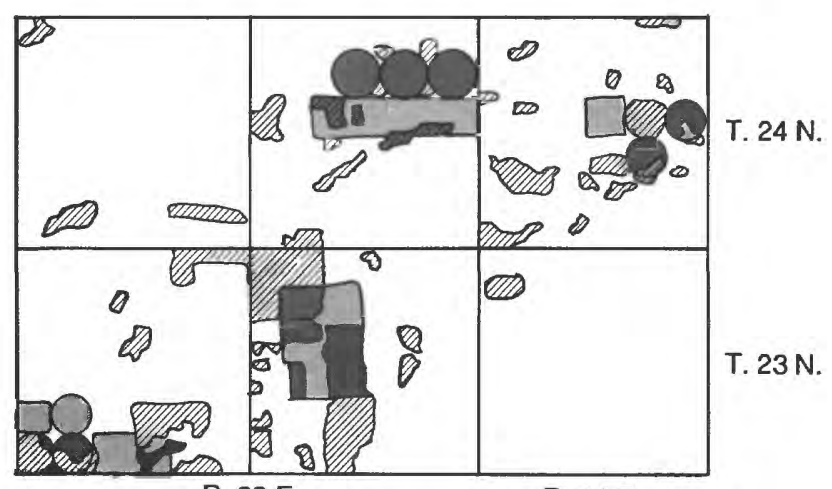

R. $33 \mathrm{E}$.

R. $34 \mathrm{E}$.

Example area c. Approximately 57 percent correct, by area.

Figure 6.--Results of Landsat thematic mapper classification for three example areas, and available ground truth. See figure 3 for location of example areas in study area. 
The 94-percent accuracy in identifying corn, potatoes, and alfalfa in the central Grant County test area using TM was not achieved over the rest of the TM analysis area. Central Grant County is slightly warmer and dryer than the rest of the TM analysis area. On a given date, crops there may be more mature than crops to the east and north. Visual inspection of a black-and-white band 5 picture of the June 22, 1985, TM image seemed to support this. Corn fields in central Grant County appeared dark and clearly were irrigated, whereas corn fields in north-central Adams County appeared light and barely were distinguishable from surrounding nonirrigated lands. This illustrates the importance of the timing of Landsat data collection. Detailed data on crop phenology for the entire study area for the year of analysis are important. If no single date will capture all crops of interest at a vigorous stage of growth over the entire study area, then a two-date approach may be necessary.

The results of this study indicate that the most promising approach for mapping crops in the Columbia Basin is to use two passes of TM data, one from middle June and one from late July or early August. 


\section{DEVELOPMENT OF A GROUND-WATER-USE MODEL}

One of the primary goals of this project was to develop a regression model for estimating annual waterapplication rates for crops irrigated with ground water on the Columbia Plateau in eastern Washington. The approach adopted to achieve that goal was as follows: (1) identify the independent variables most likely to affect water-application rates for irrigation; (2) calculate annual pumpage at a selection of sites covering the range of independent variables; (3) divide calculated pumpage by irrigated acres at those sites to yield annual water-application rates; (4) compile information at those water-application rate sample sites on each of the independent variables; and (5) develop a regression equation to predict annual water-application rates on the basis of the significant independent variables. Annual water-application rates, expressed as a depth of water, then could be calculated and multiplied by area of irrigated land (as mapped by Landsat) to yield volume of water pumped.

Initially, the variables thought to affect water-application rates were crop type, annual potential evapotranspiration, annual precipitation, available water capacity (AWC) of the soil, and total operating head (TOH) of the irrigation system. One other variable, irrigation-system type, was added after computation of application rates for the sample sites when it appeared that fields growing small grains under center pivot irrigation systems were using more water than those under wheeline and trimatic systems. (No flood or gravity systems were encountered.)

Ideally, under full irrigation, the quantity of water applied would equal the actual evapotranspiration from the soil and plants minus the water supplied by precipitation plus enough water for leaching to prevent buildup of minerals in the soil. Commonly, to calculate actual evapotranspiration for a given crop, potential evapotranspiration is calculated for a reference crop such as alfalfa, then adjusted for the given crop's growth characteristics by an empirically derived crop coefficient and limited by the amount of moisture available in the soil. The recharge model for the Columbia Plateau Regional Aquifer Systems Analysis operates in this way (Bauer and Vaccaro, 1986).

For this study, crop type was used as an independent variable in the regression analysis, so variation in application rate between crop types was accounted for by the crop independent variable. Variation within crop type due to differences in evapotranspiration from one area to another was accounted for by the potential evapotranspiration independent variable. Daily values of potential evapotranspiration, calculated at weather station sites, and daily precipitation were interpolated to the entire study area on a quarter-township ( $9 \mathrm{mi}^{2}$ ) resolution and summed over water year October 1 to September 30. Potential evapotranspiration was calculated as a function of daily incident solar radiation and average daily temperature using the Jensen-Haise radiation method as presented by Bauer and Vaccaro (1986). Water year was used to include the effects of fall weather in the climate variables which, through the buildup of moisture in the soil, will contribute to the water needs of the plants during the subsequent growing season. In contrast, power consumption data were available only for the calendar year, so the dependent variable water use was computed for the calendar year. In eastern Washington, a small amount of pumpage occurs as late as middle October. However, the amount of overlap between computing pumpage on the calendar year and calculating potential evapotranspiration and precipitation on the water year was considered insignificant. 


\section{Collection and Calculation of Pumpage Data at Sample Sites}

The primary method used for calculating pumpage was the pump efficiency-power consumption method (D. R. Cline, U.S. Geological Survey, oral commun., 1987). The efficiency of an irrigation system can be determined by simultaneously measuring the flow, the $\mathrm{TOH}$, and the power consumption of the pump. Flow was measured using an ultrasonic flow meter. TOH is the sum of the pumping water level, the line pressure, and the friction head loss calculated from the point of measurement of the line pressure to the pump intakes. Pumping water levels normally were measured by airline, line pressures were measured with a pressure gauge, and friction losses were calculated by accepted water-well industry methods. Power consumption was measured by timing the electric meter with a stop watch (all systems encountered were electrically powered). The equation to convert the above data to efficiency is:

$$
\mathrm{EFF}=(\mathrm{FLOW} \times \mathrm{TOH}) /(3,960 \times \mathrm{HP}),
$$

where:

$\mathrm{EFF}=$ the efficiency of the pump reported as a decimal; for example, 60 -percent efficiency $=0.60$;

FLOW = flow, in gallons per minute;

$\mathrm{TOH}=$ total operating head, in feet; and

HP = input horse power.

Pumpage sample-site information is limited to depth of water applied, soil type, TOH of the irrigation system, irrigation system type, and quarter-township location. Pumpage was calculated by:

$$
\mathrm{Q}=(\mathrm{KW} \times \mathrm{EFF}) /(\mathrm{TOH} \times 1.024) \text {, }
$$

where:

$Q=$ pumpage, in acre-feet; and

$\mathrm{KW}=$ amount of electricity used in an irrigation season, in kilowatt hours.

Relating pumpage from a well or system of wells to a particular crop requires that the irrigation system is watering only one crop type and that the efficiency of all wells in that system can be measured. For much of the study area, this was not a major constraint; however, in central and southern Adams County and northern Franklin County it was. In that area, large systems of interconnected wells watering a variety of crops predominate, greatly limiting the number of sample sites available using the pump efficiency approach.

An alternate method for determining water use to individual crops was tested in this area, involving the use of digital vibration time totalizers (DiVTTs). Seven DiVTTs were installed on center pivots in Adams and extreme eastern Grant Counties. In addition, built-in timers on five center pivots were read before and after the 1985 season. Sometime during the season, flow was measured at all the timed pivots. Flow multiplied by time of operation yielded total water use for that field. Unfortunately, four out of seven DiVTTs failed during the season, all in central Adams County. 
Pumpage data also were obtained from private landowners in the area, who monitored depth of water applied and soil moisture at regular intervals through the growing season. Pumpage data were estimated using measured flow to pivots, time of operation of the pivots, and inline flow meters. Annual water-application rate, crop type, and number of irrigated acres were provided to the Survey for the 1983, 1984, and 1985 growing seasons from about 100 fields each year. Independent computation of total pumpage for each system of wells for the 1983, 1984, and 1985 seasons, using the measured pump efficiency-power consumption method, compared closely with total reported pumpage (total reported pumpage $=$ application rate $\mathrm{x}$ irrigated acres).

Numbers of samples by crop category and by county and average annual water-application rate are listed in table 3. Locations of small grain sample sites are shown in figure 7, and locations of com, potatoes, and alfalfa sample sites are shown in figure 8. The irrigated acreage of each crop type, as mapped using Landsat data for 1985 , is shown also on the figures.

TABLE 3.--Water-application-rate pumpare samples by county and crop caterory

\begin{tabular}{|c|c|c|c|}
\hline County & Crop category & Number of samples & $\begin{array}{c}\text { Average annual } \\
\text { water-application } \\
\text { rate, in feet }\end{array}$ \\
\hline & \multicolumn{3}{|c|}{ U.S. Geological Survey pumpage samples } \\
\hline \multirow[t]{3}{*}{ Adams } & Small grains & 14 & 1.12 \\
\hline & High-use crops & 0 & - \\
\hline & Miscellaneous crops & 1 & 1.71 \\
\hline \multirow[t]{3}{*}{ Franklin } & Small grains & 13 & 2.23 \\
\hline & High-use crops & 100 & 2.90 \\
\hline & Miscellaneous crops & 12 & 2.18 \\
\hline \multirow[t]{3}{*}{ Grant } & Sma11 grains & 44 & 1.78 \\
\hline & High-use crops & 20 & 3.24 \\
\hline & Miscellaneous crops & 1 & 1.71 \\
\hline \multirow[t]{3}{*}{ Lincoln } & Small grains & 48 & 1.08 \\
\hline & High-use crops & 3 & 2.83 \\
\hline & Miscellaneous crops & 0 & - \\
\hline \multicolumn{4}{|c|}{ Private pumpage samples } \\
\hline \multirow[t]{3}{*}{ Adams } & Sma1l grains & 144 & 1.91 \\
\hline & High-use crops & 75 & 2.91 \\
\hline & Miscellaneous crops & 86 & 2.15 \\
\hline
\end{tabular}




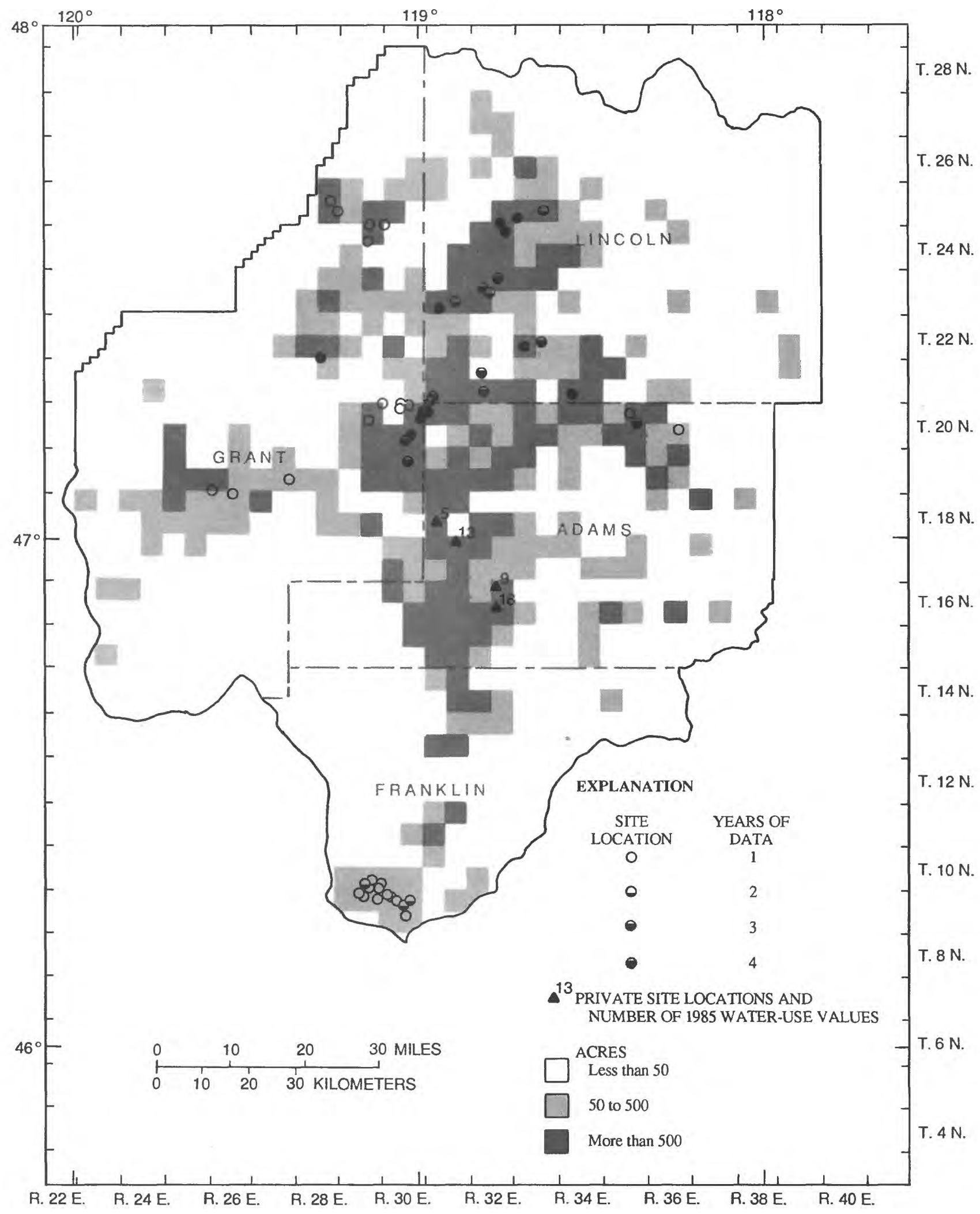

Figure 7.--Location of water-application-rate sample sites and acreage for small grains, by quarter-township, for 1985 . 


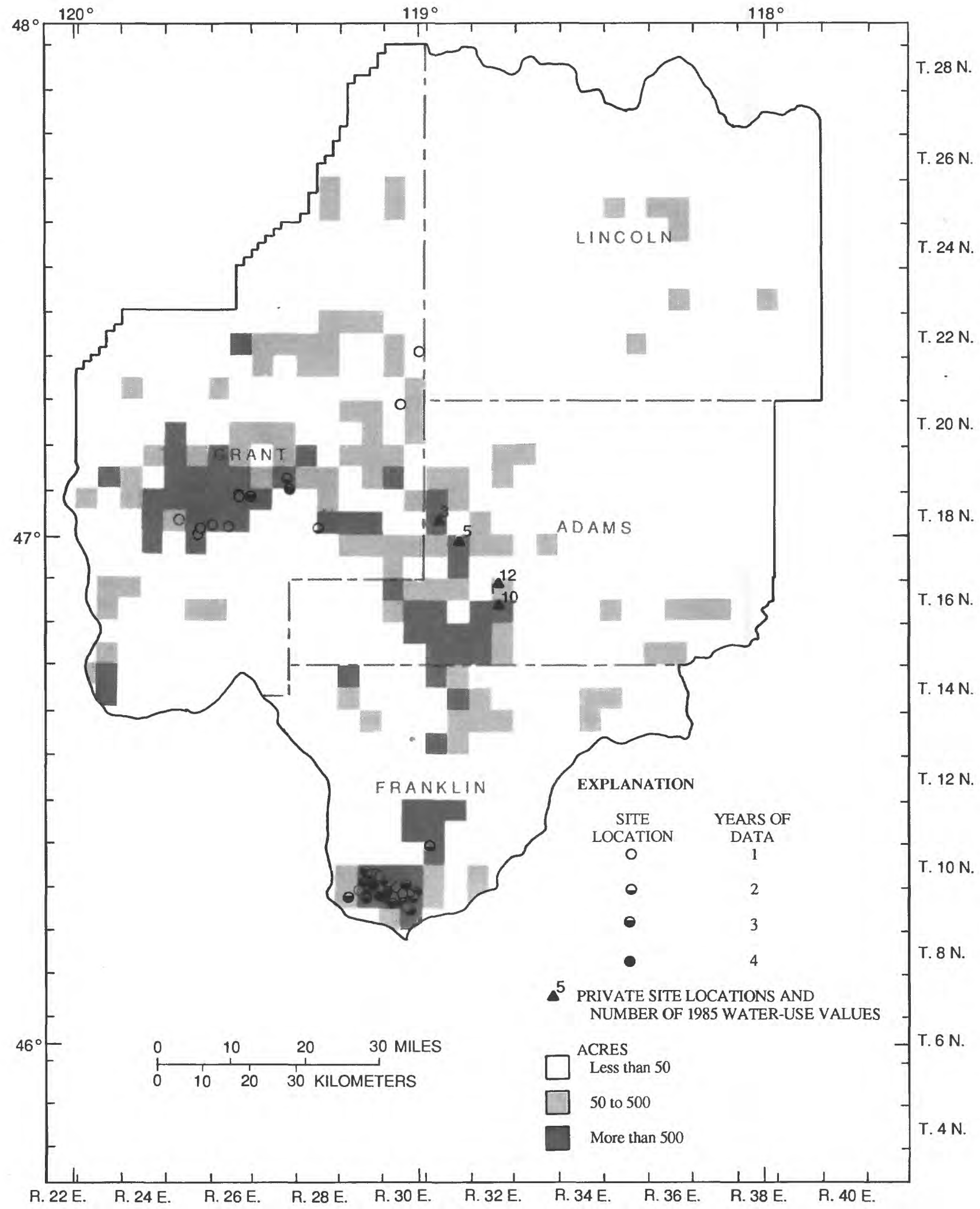

Figure 8.-Location of water-application-rate sample sites and acreage for corn, potatoes, and alfalfa, by quarter-township, for 1985 . 
Total pumpage, in acre-feet, for each water-application rate sample site for each year was divided by acres irrigated to yield depth of water applied, in feet. These annual water-application rates were used as the dependent variable in the regression analysis. A total of 576 annual water-application rate samples were obtained for the 1982 through 1985 growing seasons, 305 collected by private landowners and the rest by the U.S. Geological Survey.

\section{Water-Level and Line-Pressure Measurement}

Variation in $\mathrm{TOH}$ during the irrigation season and variation from one season to the next probably constitutes the greatest source of error in the computation of pumpage by the pump-efficiency power consumption method. Changes in water levels from one year to the next, drawdown of water levels during a year, and changes in the operating setup of the irrigation system (for example, various numbers of sprinkler systems running or adjustment of gate valves) all result in changes in $\mathrm{TOH}$. Water level and line pressure were measured three times during the 1985 growing season to better define $\mathrm{TOH}$ with time. These measurements were particularly important at sites where the efficiency was measured in previous years.

\section{Statistical Analysis}

The major crop types grown in the study area were small grains, corn (including sweet corn), potatoes, and alfalfa (including hay and pasture). Other crops grown were peas, dry beans, onions, safflower, sunflowers, asparagus, and dill.

An inspection of mean water-application rates for sampled crops indicated the possibility of grouping them into water-use categories. A frequency analysis and an ' $F$ ' test performed on application-rate data for potatoes, corn, and alfalfa showed that they could not be separated statistically with a reasonable degree of confidence (fig. 9). A probability value of 0.63 was computed, meaning there is a 63-percent probability that the application rate differences between the crops are chance differences and not group differences. This is particularly significant because corn and potatoes are difficult to separate using Landsat data. These crops are grouped together and hereafter referred to as the high water-use crops. Small grains, primarily wheat and barley, were grouped into a second crop category. Several miscellaneous row and vegetable crops were grouped into a third category.

A frequency analysis and an ' $F$ ' test on water-application rate values showed that the three crop categories, small grains, high water-use crops, and miscellaneous row and vegetable crops, use significantly different quantities of water. The ' $F$ ' test showed there is less than a 1-percent probability that the application rate differences between the crops are chance differences and not group differences. Histograms of water-application rates for the three crop categories are shown in figure 9. 
a.

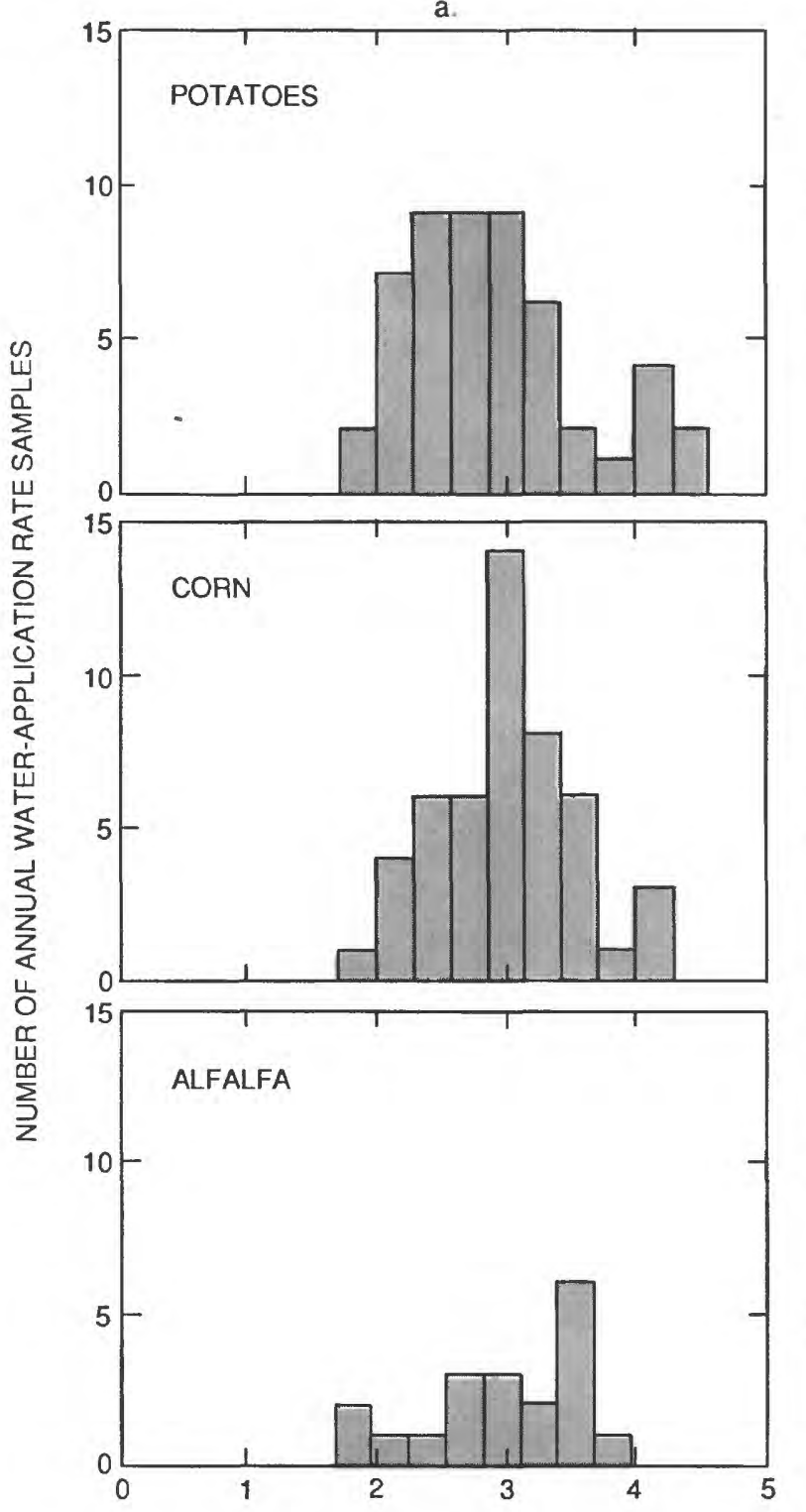

b.
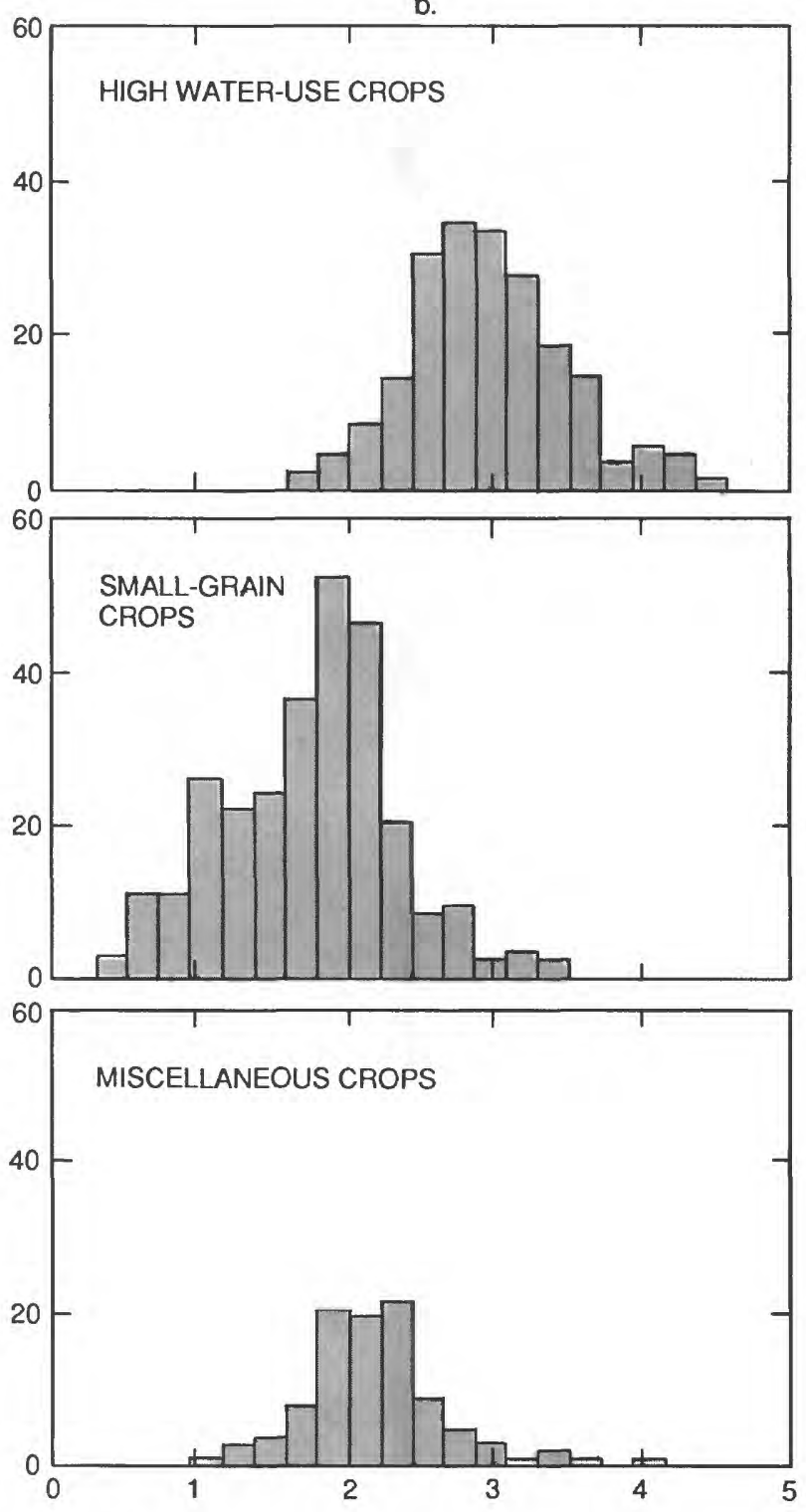

WATER USE, IN FEET

Figure 9.--Histograms of water-application rates for (a) sampled crops, (b) three crop categories. 
Regression analysis was applied to 576 values of annual water-application rate for 1982 through 1985 . The independent variables considered in these analyses were crop type, annual potential evapotranspiration, annual precipitation, AWC of the soil, TOH of the irrigation system, and irrigation system type. System type was distinguished as either center pivot or other, with a value of one used for center pivot and a value of zero used for other. The statistical algorithm used could recognize only numeric values; therefore, class variables such as system type and crop type were entered as combinations of zeros and ones. Class variable names used and values assigned are listed in table 4.

TABLE 4,--Method of assigning values to class variables for regression analysis

\begin{tabular}{lclcc}
\hline & Variable & & \multicolumn{2}{c}{ 'Dummy' variables } \\
\cline { 3 - 5 } System type & SYS & Crop category & K1 & K2 \\
\hline Center pivot & 1 & Small grains & 0 & 0 \\
Noncenter pivot & 0 & Miscellaneous vegetable & & \\
& & and row crops & 1 & 0 \\
& & High water-use crops & 0 & 1 \\
& & &
\end{tabular}

Four independent variables were included in the resulting regression equation to predict annual waterapplication rates: crop type, annual precipitation, irrigation system type, and AWC of the soil. Annual potential evapotranspiration and TOH were not included as independent variables because both showed a low correlation with water-application rates and a relatively high correlation with one of the other independent variables.

The multiple $\mathrm{R}$ squared value for the regression equation, the proportion of variance in the dependent variable that is explained by the independent variables, is 0.623 . The regression equation is:

$$
\mathrm{RATE}=0.2805 \mathrm{~K} 1+0.9078 \mathrm{~K} 2-0.0601 \text { precipitation }+0.6704 \mathrm{SYS}-2.210 \mathrm{AWC}+2.238
$$

where:

RATE $=$ predicted annual water-application rate, as a depth of water, in feet;

$\mathrm{K} 1$ and $\mathrm{K} 2$ = crop variables (see table 4);

precipitation = annual precipitation, in inches;

SYS = irrigation system type (see table 4); and

AWC $=$ available water capacity of the soil, in inches per inch.

Predicted application rate was within 15 percent of observed for 60 percent of the samples, and was within 25 percent of observed for 79 percent of the samples. The distribution of the residuals for 569 of 576 waterapplication rate samples (fig. 10) was calculated by: residual = (observed application rate - predicted application rate)/observed application rate. The seven samples not shown had residuals of less than -1.0. All seven were supplementally irrigated wheat with observed application rates of approximately 0.5 foot or less. The mean residual for all 576 samples was -0.062 , and the standard deviation was 0.328 . The residual, as calculated here, times 100 , equals the percentage difference between the predicted application rate and the observed application rate. 


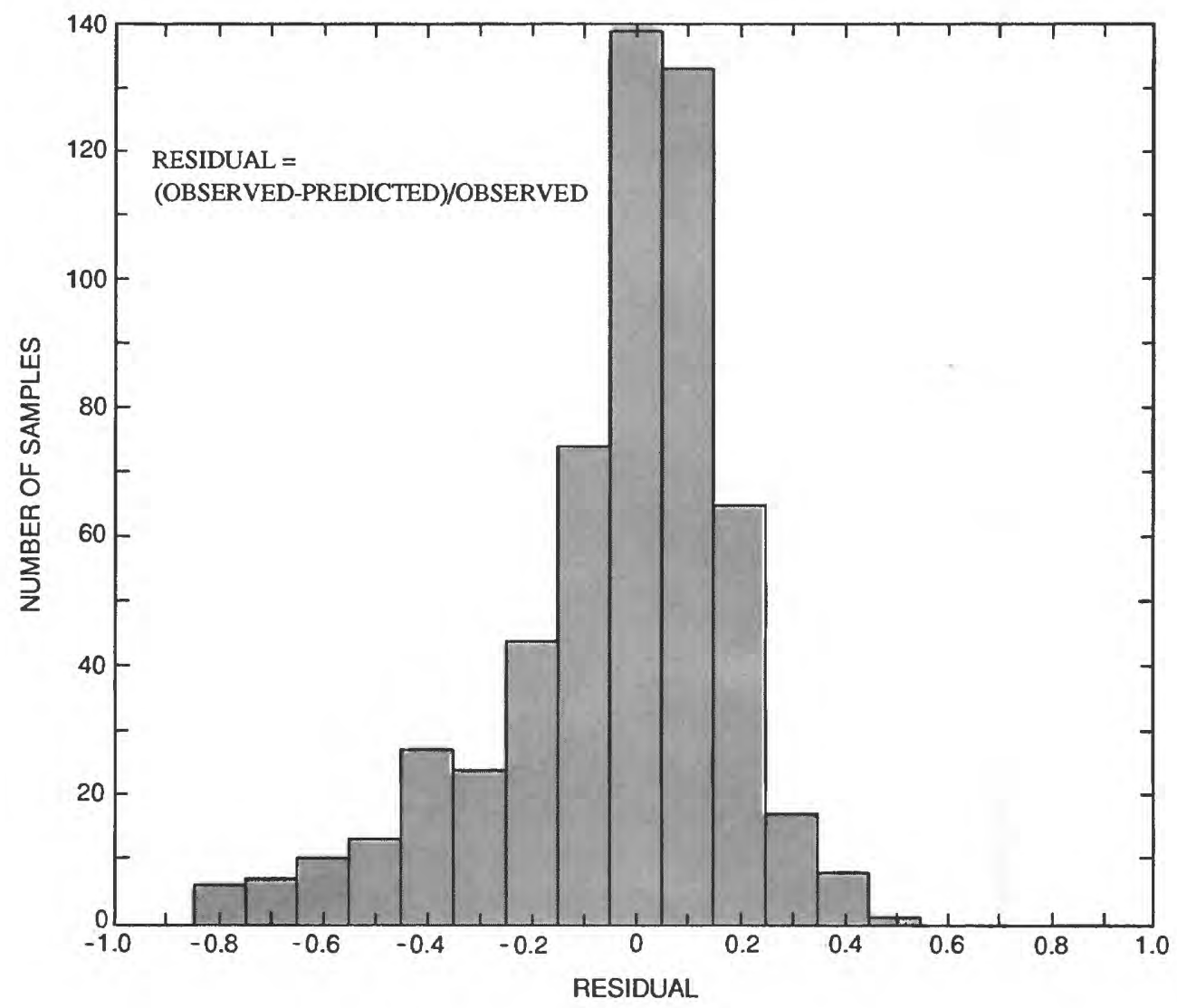

Figure 10.--Residual of regression-predicted water-application rates for sample sites. 


\section{CALCULATION OF PUMPAGE}

Inclusion of irrigation-system type as an independent variable in the regression equation meant that it had to be identified areawide before pumpage could be computed. System type was assigned on the basis of field shape--round fields being center pivot, not round being noncenter pivot. Portions of circles and center pivot corner systems, which irrigate the corners of fields, were identified as center pivot, where recognized.

A plot of the classified Landsat image, a plot of well locations, and July 9, 1985, Landsat prints at 1:250,000 scale were used to identify circles visually and to estimate the acreage of center pivot small grains by quarter-township. Acres of center pivot small grains were input to the computer manually, then subtracted from total acres of irrigated small grains, by quarter-township, to obtain acres of noncenter pivot small grains.

One final problem had to be addressed before computation of pumpage could be completed. Identification of irrigated fields using Landsat yielded the point of application of the water, but not necessarily the point of withdrawal. Ideally, the tie between all irrigated fields and the wells serving them would be known, so pumpage estimated for an acreage could be assigned to a specific well. This information is not available currently, and because of the large number of irrigation systems involved and because most of the pipes feeding water to the fields are buried, it would not be obtained easily.

Another approach had to be developed to make the association of irrigated fields to wells. The groundwater/surface-water mask used in the Landsat analysis (see fig. 2) was overlaid with band 2 Landsat images at 1:250,000 scale. Irrigated fields that fell within the same quarter-township as a well or wells were assumed to be supplied by those wells. Irrigated fields that fell in a quarter-township where no wells were located were assigned to the adjacent quarter-township with a well whose buffer zone included them or to the quarter-township with the closest well if buffer zones overlapped.

Irrigated acreage (mapped using Landsat analysis) by crop category was summed for all quarter-townships containing active irrigation wells, including acreage from adjacent quarter-townships that had been assigned manually to them. Pumpage then was estimated by multiplying irrigated acres times water-application rates calculated using the regression equation

$$
\text { Pumpage }=\text { RATE(1) } \times \operatorname{ACRES}(1)+\operatorname{RATE}(2) \times \operatorname{ACRES}(2)+\ldots+\operatorname{RATE}(\mathrm{N}) \times \operatorname{ACRES}(\mathrm{N})
$$

where:

Pumpage = pumpage in acre-feet, for a quarter-township;

RATE(1), RATE $(N)$ = water-application rates calculated for each crop present in a quarter-township, using equation 3 , in feet; and

ACRES(1), ACRES(N) = acres of each crop in a quarter-township mapped using Landsat data, in acres.

The 1985 values for AWC, precipitation for the 1985 water year, estimated application rates by crop category, irrigated acreage, and pumpage are listed in table 5, and pumpage is shown on figure 11. A summary of irrigated acreage and water use by county is listed in table 6 and shown on figure 12. Total pumpage for the study area was about 620,000 acre feet. 
TABLE 5. Ground-water pumpage, irrigated acreace, and application rates for 1985

\begin{tabular}{|c|c|c|c|c|c|c|c|c|c|}
\hline $\begin{array}{l}\text { Quarter- } \\
\text { township } \\
\end{array}$ & $\begin{array}{l}\text { Available } \\
\text { water cap- } \\
\text { acity, in } \\
\text { inches } \\
\text { per inch }\end{array}$ & $\begin{array}{l}\text { Precipi- } \\
\text { tation } \\
\text { for water } \\
\text { year } 1985 \text {, } \\
\text { in inches }\end{array}$ & $\begin{array}{l}\text { Noncenter } \\
\text { small gral } \\
\text { Application } \\
\text { rate, in } \\
\text { feet }\end{array}$ & $\begin{array}{l}\text { pivot } \\
\text { ins } \\
\text { Acres }\end{array}$ & $\begin{array}{l}\text { Center piv } \\
\text { small grai } \\
\text { Application } \\
\text { rate, in } \\
\text { feet }\end{array}$ & $\begin{array}{l}\text { vot } \\
\text { ins }\end{array}$ & $\begin{array}{l}\text { High wate } \\
\text { use crops } \\
\text { Application } \\
\text { rate, in } \\
\text { feet }\end{array}$ & $\begin{array}{l}\text { er- } \\
s\end{array}$ & $\begin{array}{l}\text { Pumpage, } \\
\text { in acre- } \\
\text { feet }\end{array}$ \\
\hline $9 N / 29 E-N E$ & 0.10 & 6.10 & 1.65 & 0 & 2.32 & 570 & 3.23 & 2,609 & 9,700 \\
\hline $9 N / 30 E-N E$ & .13 & 6.57 & 1.56 & 0 & 2.23 & 189 & 3.13 & 3,436 & 11,200 \\
\hline $9 N / 30 E-N W$ & .11 & 6.22 & 1.62 & 0 & 2.29 & 281 & 3.20 & 2,106 & 7,400 \\
\hline 9N/30E-SW & .11 & 6.03 & 1.63 & 0 & 2.30 & 117 & 3.21 & 327 & 1,300 \\
\hline 9N/30E-SE & .11 & 6.38 & 1.61 & 0 & 2.28 & 317 & 3.19 & 1,198 & 4,500 \\
\hline 9N/31E-NE & .15 & 7.76 & 1.44 & 0 & 2.11 & 430 & 3.02 & 0 & 910 \\
\hline $9 N / 32 E-N W$ & .13 & 7.89 & 1.48 & 0 & 2.15 & 399 & 3.05 & 641 & 2,800 \\
\hline $10 N / 29 E-S E$ & .10 & 6.35 & 1.64 & 0 & 2.31 & 607 & 3.21 & 1,634 & 6,600 \\
\hline $10 \mathrm{~N} / 30 \mathrm{E}-\mathrm{SW}$ & .13 & 6.52 & 1.56 & 0 & 2.23 & 310 & 3.14 & 709 & 2,900 \\
\hline 1ON/3OE-SE & .13 & 6.75 & 1.54 & 0 & 2.22 & 407 & 3.12 & 1,507 & 5,600 \\
\hline $10 N / 31 E-N W$ & .08 & 7.28 & 1.62 & 0 & 2.29 & 231 & 3.20 & 2,212 & 7,600 \\
\hline $11 N / 30 E-S E$ & .13 & 7.10 & 1.52 & 0 & 2.19 & 286 & 3.10 & 1,164 & 4,200 \\
\hline $11 N / 31 E-N E$ & .19 & 7.74 & 1.35 & 0 & 2.02 & 799 & 2.93 & 1,086 & 4,800 \\
\hline $11 N / 31 E-N W$ & .18 & 7.45 & 1.39 & 0 & 2.06 & 295 & 2.97 & 633 & 2,500 \\
\hline $11 N / 31 E-S W$ & .08 & 7.39 & 1.62 & 0 & 2.29 & 1,279 & 3.19 & 2,457 & 10,800 \\
\hline $13 N / 29 E-N E$ & .13 & 6.68 & 1.56 & 0 & 2.22 & 0 & 3.13 & 270 & 850 \\
\hline $13 N / 31 E-N E$ & .15 & 6.89 & 1.49 & 166 & 2.16 & 260 & 3.07 & 284 & 1,700 \\
\hline $13 N / 31 E-S W$ & .15 & 7.04 & 1.48 & 229 & 2.15 & 390 & 3.06 & 552 & 2,900 \\
\hline 13N/31E-SE & .15 & 7.37 & 1.46 & 417 & 2.13 & 260 & 3.04 & 147 & 1,600 \\
\hline $13 N / 32 E-N E$ & .18 & 7.97 & 1.36 & 125 & 2.03 & 0 & 2.94 & 383 & 1,300 \\
\hline 13N/32E-NW & .15 & 7.32 & 1.47 & 71 & 2.14 & 0 & 3.04 & 154 & 570 \\
\hline $14 N / 23 E-N E$ & .09 & 4.63 & 1.76 & 18 & 2.43 & 0 & 3.34 & 2,360 & 7,900 \\
\hline $14 \mathrm{~N} / 29 \mathrm{E}-\mathrm{NW}$ & .10 & 6.44 & 1.63 & 0 & 2.30 & 0 & 3.21 & 900 & 2,900 \\
\hline $14 \mathrm{~N} / 29 \mathrm{E}-\mathrm{SW}$ & .15 & 6.52 & 1.51 & 0 & 2.18 & 0 & 3.09 & 121 & 370 \\
\hline $14 \mathrm{~N} / 31 \mathrm{E}-\mathrm{NW}$ & .18 & 6.63 & 1.44 & 0 & 2.11 & 826 & 3.02 & 2,028 & 7,900 \\
\hline $14 \mathrm{~N} / 31 \mathrm{E}-\mathrm{SE}$ & .15 & 6.61 & 1.51 & 582 & 2.18 & 260 & 3.09 & 1,453 & 5,900 \\
\hline $14 \mathrm{~N} / 32 \mathrm{E}-\mathrm{SW}$ & .16 & 7.04 & 1.46 & 466 & 2.13 & 130 & 3.04 & 426 & 2,300 \\
\hline $14 \mathrm{~N} / 34 \mathrm{E}-\mathrm{SE}$ & .18 & 8.98 & 1.30 & 0 & 1.97 & 0 & 2.88 & 340 & 980 \\
\hline $14 \mathrm{~N} / 35 \mathrm{E}-\mathrm{SW}$ & .18 & 8.89 & 1.31 & 167 & 1.98 & 0 & 2.88 & 389 & 1,300 \\
\hline $15 N / 23 E-S E$ & .09 & 4.93 & 1.74 & 0 & 2.41 & 107 & 3.32 & 151 & 760 \\
\hline $15 N / 24 E-S W$ & .13 & 5.08 & 1.65 & 0 & 2.32 & 0 & 3.22 & 38 & 120 \\
\hline $15 \mathrm{~N} / 30 \mathrm{E}-\mathrm{NE}$ & .18 & 6.34 & 1.46 & 764 & 2.13 & 130 & 3.04 & 607 & 3,200 \\
\hline $15 N / 31 E-N E$ & .18 & 7.05 & 1.42 & 0 & 2.09 & 1,001 & 2.99 & 703 & 4,200 \\
\hline $15 N / 31 E-N W$ & .18 & 6.63 & 1.44 & 0 & 2.11 & 1,688 & 3.02 & 711 & 5,700 \\
\hline 15N/31E-SW & .18 & 6.65 & 1.44 & 469 & 2.11 & 130 & 3.02 & 1,442 & 5,300 \\
\hline $15 N / 31 E-S E$ & .18 & 6.96 & 1.42 & 604 & 2.09 & 260 & 3.00 & 500 & 2,900 \\
\hline $15 N / 32 E-N W$ & .18 & 7.58 & 1.38 & 367 & 2.05 & 390 & 2.96 & 1,413 & 5,500 \\
\hline $15 N / 32 E-S W$ & .18 & 7.47 & 1.39 & 384 & 2.06 & 0 & 2.97 & 559 & 2,200 \\
\hline 15N/32E-SE & .20 & 8.22 & 1.30 & 48 & 1.97 & 0 & 2.88 & 323 & 990 \\
\hline $15 N / 34 E-S E$ & .16 & 8.79 & 1.36 & 116 & 2.03 & 0 & 2.93 & 24 & 230 \\
\hline
\end{tabular}


TABLE 5. Ground-water pumpage, irrigated acreage, and application rates for 1985--continued

\begin{tabular}{|c|c|c|c|c|c|c|c|c|c|}
\hline $\begin{array}{l}\text { Quarter- } \\
\text { township }\end{array}$ & $\begin{array}{l}\text { Available } \\
\text { water cap- } \\
\text { acity, in } \\
\text { inches } \\
\text { per inch }\end{array}$ & $\begin{array}{l}\text { Precipi- } \\
\text { tation } \\
\text { for water } \\
\text { year } 1985, \\
\text { in inches }\end{array}$ & $\begin{array}{l}\text { Noncenter pi } \\
\text { small grai } \\
\text { Application } \\
\text { rate, in } \\
\text { feet }\end{array}$ & $\begin{array}{l}\text { ivot } \\
\text { ins }\end{array}$ & $\begin{array}{l}\text { Center pi } \\
\text { smal1 gra } \\
\text { Application } \\
\text { rate, in } \\
\text { feet }\end{array}$ & $\begin{array}{l}\text { vot } \\
\text { ins }\end{array}$ & $\begin{array}{l}\text { High wat } \\
\text { use crop } \\
\text { Application } \\
\text { rate, in } \\
\text { feet }\end{array}$ & $\begin{array}{l}\text { er- } \\
\text { s }\end{array}$ & $\begin{array}{l}\text { Pumpage, } \\
\text { in acre- } \\
\text { feet }\end{array}$ \\
\hline $15 N / 36 E-S W$ & 0.18 & 9.92 & 1.24 & 36 & 1.92 & 0 & 2.82 & 331 & 980 \\
\hline $15 N / 37 E-S E$ & .20 & 11.78 & 1.09 & 20 & 1.76 & 0 & 2.67 & 14 & 60 \\
\hline $16 \mathrm{~N} / 23 \mathrm{E}-\mathrm{NE}$ & .09 & 5.62 & 1.70 & 9 & 2.37 & 130 & 3.28 & 186 & 930 \\
\hline $16 \mathrm{~N} / 23 \mathrm{E}-\mathrm{SE}$ & .09 & 5.42 & 1.71 & 0 & 2.38 & 0 & 3.29 & 54 & 180 \\
\hline $16 N / 24 E-N W$ & .10 & 5.71 & 1.67 & 0 & 2.34 & 144 & 3.25 & 389 & 1,600 \\
\hline $16 N / 25 E-S E$ & .22 & 5.72 & 1.41 & 0 & 2.08 & 0 & 2.99 & 170 & 510 \\
\hline $16 \mathrm{~N} / 26 \mathrm{E}-\mathrm{SW}$ & .13 & 5.75 & 1.60 & 22 & 2.28 & 0 & 3.18 & 264 & 870 \\
\hline $16 \mathrm{~N} / 26 \mathrm{E}-\mathrm{SE}$ & .18 & 5.83 & 1.49 & 9 & 2.16 & 0 & 3.07 & 36 & 130 \\
\hline $16 \mathrm{~N} / 30 \mathrm{E}-\mathrm{NW}$ & .18 & 6.52 & 1.45 & 388 & 2.12 & 450 & 3.03 & 1,007 & 4,600 \\
\hline $16 \mathrm{~N} / 30 \mathrm{E}-\mathrm{SE}$ & .17 & 6.41 & 1.48 & 960 & 2.15 & 1,560 & 3.05 & 1,626 & 9,700 \\
\hline $16 N / 31 E-N E$ & .18 & 7.17 & 1.41 & 0 & 2.08 & 1,010 & 2.99 & 374 & 4,500 \\
\hline $16 N / 31 E-N W$ & .18 & 6.83 & 1.43 & 0 & 2.10 & 846 & 3.01 & 239 & 3,000 \\
\hline $16 N / 31 E-S W$ & .18 & 6.67 & 1.44 & 0 & 2.11 & 1,107 & 3.02 & 625 & 5,800 \\
\hline $16 \mathrm{~N} / 31 \mathrm{E}-\mathrm{SE}$ & .18 & 7.07 & 1.42 & 759 & 2.09 & 0 & 2.99 & 38 & 1,500 \\
\hline $16 \mathrm{~N} / 32 \mathrm{E}-\mathrm{NE}$ & .18 & 7.85 & 1.37 & 0 & 2.04 & 1,285 & 2.95 & 405 & 4,700 \\
\hline $16 \mathrm{~N} / 32 \mathrm{E}-\mathrm{NW}$ & .20 & 7.53 & 1.34 & 0 & 2.01 & 267 & 2.92 & 24 & 750 \\
\hline $16 N / 32 E-S W$ & .18 & 7.53 & 1.39 & 0 & 2.06 & 1,072 & 2.97 & 513 & 4,900 \\
\hline 16N/32E-SE & .18 & 7.99 & 1.36 & 0 & 2.03 & 1,878 & 2.94 & 1,085 & 8,100 \\
\hline 16N/33E-SW & .18 & 8.42 & 1.33 & 283 & 2.00 & 0 & 2.91 & 0 & 380 \\
\hline $16 N / 35 E-S W$ & .18 & 8.83 & 1.31 & 986 & 1.98 & 242 & 2.89 & 104 & 2,100 \\
\hline $16 \mathrm{~N} / 36 \mathrm{E}-\mathrm{NE}$ & .14 & 10.23 & 1.31 & 44 & 1.98 & 0 & 2.89 & 0 & 60 \\
\hline $16 \mathrm{~N} / 36 \mathrm{E}-\mathrm{SE}$ & .18 & 10.39 & 1.22 & 774 & 1.89 & 130 & 2.79 & 185 & 1,700 \\
\hline 16N/37E-SE & .18 & 11.90 & 1.12 & 70 & 1.80 & 0 & 2.70 & 277 & 830 \\
\hline $17 N / 24 E-N E$ & .14 & 6.17 & 1.56 & 0 & 2.23 & 388 & 3.14 & 517 & 2,500 \\
\hline $17 N / 25 E-N E$ & .10 & 6.28 & 1.64 & 0 & 2.31 & 101 & 3.22 & 1,000 & 3,500 \\
\hline $17 N / 30 E-N E$ & .18 & 6.95 & 1.42 & 358 & 2.09 & 0 & 3.00 & 269 & 1,300 \\
\hline $17 \mathrm{~N} / 30 \mathrm{E}-\mathrm{NW}$ & .18 & 6.86 & 1.43 & 0 & 2.10 & 64 & 3.01 & 210 & 770 \\
\hline $17 \mathrm{~N} / 30 \mathrm{E}-\mathrm{SW}$ & .15 & 6.69 & 1.50 & 585 & 2.17 & 0 & 3.08 & 129 & 1,300 \\
\hline 17N/30E-SE & .19 & 6.73 & 1.41 & 236 & 2.08 & 130 & 2.99 & 23 & 670 \\
\hline $17 N / 31 E-N E$ & .17 & 7.44 & 1.41 & 0 & 2.09 & 2,520 & 2.99 & 796 & 9,000 \\
\hline 17N/31E-SE & .18 & 7.29 & 1.40 & 176 & 2.07 & 609 & 2.98 & 603 & 3,800 \\
\hline $17 N / 32 E-N E$ & .20 & 8.00 & 1.31 & 345 & 1.99 & 171 & 2.89 & 58 & 1,100 \\
\hline $17 N / 32 E-N W$ & .18 & 7.70 & 1.38 & 668 & 2.05 & 1,110 & 2.96 & 269 & 5,300 \\
\hline $17 N / 32 E-S W$ & .18 & 7.57 & 1.38 & 230 & 2.06 & 0 & 2.96 & 0 & 320 \\
\hline $17 N / 33 E-N E$ & .18 & 8.08 & 1.35 & 54 & 2.02 & 0 & 2.93 & 59 & 240 \\
\hline $17 \mathrm{~N} / 33 \mathrm{E}-\mathrm{NW}$ & .18 & 8.10 & 1.35 & 179 & 2.02 & 149 & 2.93 & 46 & 770 \\
\hline $17 N / 34 E-N W$ & .18 & 8.13 & 1.35 & 107 & 2.02 & 0 & 2.93 & 29 & 230 \\
\hline $17 N / 34 E-S E$ & .18 & 8.46 & 1.33 & 81 & 2.00 & 0 & 2.91 & 48 & 280 \\
\hline $17 \mathrm{~N} / 35 \mathrm{E}-\mathrm{NE}$ & .16 & 9.10 & 1.34 & 371 & 2.01 & 0 & 2.92 & 0 & 500 \\
\hline $17 N / 35 E-S E$ & .18 & 9.09 & 1.29 & 420 & 1.96 & 0 & 2.87 & 0 & 540 \\
\hline
\end{tabular}


TABLE 5. Ground-water pumpage, irrigated acreage, and application rates for 1985--continued

\begin{tabular}{|c|c|c|c|c|c|c|c|c|c|}
\hline $\begin{array}{l}\text { Quarter- } \\
\text { township }\end{array}$ & $\begin{array}{l}\text { Available } \\
\text { water cap- } \\
\text { acity, in } \\
\text { inches } \\
\text { per inch }\end{array}$ & $\begin{array}{l}\text { Precipi- } \\
\text { tation } \\
\text { for water } \\
\text { year 1985, } \\
\text { in inches }\end{array}$ & $\begin{array}{l}\text { Noncenter } \\
\text { small gr } \\
\text { Applicatior } \\
\text { rate, in } \\
\text { feet }\end{array}$ & $\begin{array}{l}\text { pivot } \\
\frac{\text { ains }}{n} \\
\text { Acres }\end{array}$ & $\begin{array}{l}\text { Center pi } \\
\text { small grai } \\
\text { Application } \\
\text { rate, in } \\
\text { feet }\end{array}$ & vot & $\begin{array}{l}\text { High wate } \\
\text { use crops } \\
\text { Application } \\
\text { rate, in } \\
\text { feet }\end{array}$ & er- & $\begin{array}{l}\text { Pumpage, } \\
\text { in acre- } \\
\text { feet }\end{array}$ \\
\hline $17 N / 36 E-S W$ & 0.16 & 9.55 & 1.31 & 28 & 1.98 & 0 & 2.89 & 0 & 40 \\
\hline $17 N / 37 E-N W$ & .13 & 10.32 & 1.33 & 122 & 2.00 & 0 & 2.91 & 0 & 160 \\
\hline $17 N / 37 E-S W$ & .14 & 10.63 & 1.29 & 31 & 1.96 & 0 & 2.87 & 0 & 40 \\
\hline $18 \mathrm{~N} / 23 \mathrm{E}-\mathrm{NW}$ & .10 & 6.60 & 1.62 & 0 & 2.29 & 415 & 3.20 & 154 & 1,400 \\
\hline $18 \mathrm{~N} / 24 \mathrm{E}-\mathrm{NE}$ & .09 & 6.76 & 1.63 & 0 & 2.30 & 129 & 3.21 & 1,640 & 5,600 \\
\hline $18 \mathrm{~N} / 24 \mathrm{E}-\mathrm{NW}$ & .11 & 6.80 & 1.59 & 0 & 2.26 & 138 & 3.16 & 474 & 1,800 \\
\hline $18 \mathrm{~N} / 24 \mathrm{E}-\mathrm{SE}$ & .09 & 6.51 & 1.65 & 0 & 2.32 & 443 & 3.23 & 1,181 & 5,200 \\
\hline $18 \mathrm{~N} / 25 \mathrm{E}-\mathrm{NE}$ & .09 & 6.71 & 1.64 & 0 & 2.31 & 403 & 3.21 & 1,451 & 5,600 \\
\hline $18 \mathrm{~N} / 25 \mathrm{E}-\mathrm{NW}$ & .09 & 6.71 & 1.64 & 0 & 2.31 & 723 & 3.21 & 1,896 & 8,000 \\
\hline $18 N / 25 E-S W$ & .09 & 6.53 & 1.65 & 0 & 2.32 & 264 & 3.22 & 451 & 2,400 \\
\hline $18 \mathrm{~N} / 25 \mathrm{E}-\mathrm{SE}$ & .09 & 6.55 & 1.65 & 0 & 2.32 & 453 & 3.22 & 2,694 & 9,700 \\
\hline $18 N / 26 E-N E$ & .09 & 6.91 & 1.62 & 0 & 2.29 & 264 & 3.20 & 1,350 & 4,900 \\
\hline $18 N / 26 E-N W$ & .09 & 6.77 & 1.63 & 0 & 2.30 & 386 & 3.21 & 668 & 3,000 \\
\hline $18 \mathrm{~N} / 26 \mathrm{E}-\mathrm{SW}$ & .09 & 6.64 & 1.64 & 0 & 2.31 & 256 & 3.22 & 2,596 & 9,000 \\
\hline $18 N / 26 E-S E$ & .09 & 6.79 & 1.63 & 0 & 2.30 & 242 & 3.21 & 768 & 3,000 \\
\hline $18 N / 27 E-N W$ & .09 & 7.11 & 1.61 & 0 & 2.28 & 585 & 3.19 & 1,137 & 5,000 \\
\hline $18 N / 28 E-N E$ & .14 & 7.33 & 1.49 & 0 & 2.16 & 203 & 3.07 & 101 & 750 \\
\hline $18 \mathrm{~N} / 28 \mathrm{E}-\mathrm{SE}$ & .13 & 7.16 & 1.52 & 0 & 2.19 & 392 & 3.10 & 662 & 2,900 \\
\hline $18 N / 29 E-S W$ & .09 & 7.09 & 1.61 & 0 & 2.28 & 366 & 3.19 & 1,075 & 4,300 \\
\hline 18N/29E-SE & .09 & 7.06 & 1.61 & 0 & 2.28 & 526 & 3.19 & 1,630 & 6,400 \\
\hline 18N/30E-NE & .18 & 7.42 & 1.39 & 418 & 2.06 & 0 & 2.97 & 83 & 830 \\
\hline $18 \mathrm{~N} / 31 \mathrm{E}-\mathrm{NE}$ & .18 & 7.69 & 1.38 & 1,604 & 2.05 & 500 & 2.96 & 318 & 5,100 \\
\hline $18 N / 31 E-N W$ & .18 & 7.51 & 1.39 & 0 & 2.06 & 1,724 & 2.97 & 527 & 5,600 \\
\hline $18 \mathrm{~N} / 31 \mathrm{E}-\mathrm{SW}$ & .18 & 7.43 & 1.39 & 0 & 2.06 & 849 & 2.97 & 638 & 3,600 \\
\hline $18 \mathrm{~N} / 32 \mathrm{E}-\mathrm{SW}$ & .18 & 7.90 & 1.37 & 1,545 & 2.04 & 910 & 2.94 & 256 & 6,200 \\
\hline $18 \mathrm{~N} / 34 \mathrm{E}-\mathrm{SW}$ & .18 & 8.10 & 1.35 & 58 & 2.02 & 0 & 2.93 & 0 & 80 \\
\hline $18 \mathrm{~N} / 37 \mathrm{E}-\mathrm{NW}$ & .14 & 9.95 & 1.33 & 166 & 2.00 & 520 & 2.91 & 0 & 1,300 \\
\hline $18 \mathrm{~N} / 38 \mathrm{E}-\mathrm{NW}$ & .18 & 10.83 & 1.19 & 355 & 1.86 & 0 & 2.77 & 0 & 420 \\
\hline $19 N / 23 E-S E$ & .14 & 6.98 & 1.51 & 0 & 2.18 & 0 & 3.09 & 964 & 3,000 \\
\hline $19 \mathrm{~N} / 24 \mathrm{E}-\mathrm{SW}$ & .09 & 6.96 & 1.62 & 0 & 2.29 & 41 & 3.20 & 255 & 910 \\
\hline $19 N / 25 E-N E$ & .09 & 6.79 & 1.63 & 0 & 2.30 & 4 & 3.21 & 373 & 1,200 \\
\hline $19 N / 25 E-N W$ & .09 & 6.89 & 1.62 & 0 & 2.30 & 574 & 3.20 & 2,845 & 10,400 \\
\hline $19 N / 25 E-S W$ & .09 & 6.83 & 1.63 & 0 & 2.30 & 788 & 3.21 & 2,567 & 10,100 \\
\hline $19 N / 25 E-S E$ & .09 & 6.79 & 1.63 & 0 & 2.30 & 1,221 & 3.21 & 2,621 & 11,200 \\
\hline $19 N / 26 E-N E$ & .10 & 6.85 & 1.61 & 0 & 2.28 & 138 & 3.18 & 198 & 940 \\
\hline $19 N / 26 E-N W$ & .10 & 6.77 & 1.61 & 0 & 2.28 & 0 & 3.19 & 1,196 & 3,800 \\
\hline $19 N / 26 E-S W$ & .09 & 6.81 & 1.63 & 0 & 2.30 & 1,264 & 3.21 & 1,540 & 7,900 \\
\hline $19 N / 26 E-5 E$ & .09 & 6.93 & 1.62 & 0 & 2.29 & 177 & 3.20 & 1,662 & 6,000 \\
\hline $19 N / 27 \mathrm{E}-\mathrm{NE}$ & .12 & 7.21 & 1.54 & 119 & 2.21 & 0 & 3.12 & 415 & 1,500 \\
\hline $19 N / 27 E-S W$ & .09 & 7.12 & 1.61 & 0 & 2.28 & 305 & 3.19 & 381 & 1,900 \\
\hline
\end{tabular}


TABLE 5. Ground-water pumpage, irrigated acrease, and application rates for 1985--continued

\begin{tabular}{|c|c|c|c|c|c|c|c|c|c|}
\hline $\begin{array}{l}\text { Quarter- } \\
\text { township }\end{array}$ & $\begin{array}{l}\text { Available } \\
\text { water cap- } \\
\text { acity, in } \\
\text { inches } \\
\text { per inch }\end{array}$ & $\begin{array}{l}\text { Precipi- } \\
\text { tation } \\
\text { for water } \\
\text { year } 1985, \\
\text { in inches }\end{array}$ & $\begin{array}{l}\text { Noncenter p } \\
\text { sma1l gra } \\
\text { Application } \\
\text { rate, in } \\
\text { feet }\end{array}$ & $\begin{array}{l}\text { pivot } \\
\frac{\text { ains }}{n} \\
\text { Acres }\end{array}$ & $\begin{array}{l}\text { Center piv } \\
\text { smal1 grai } \\
\text { Application } \\
\text { rate, in } \\
\text { feet }\end{array}$ & ins & $\begin{array}{l}\text { High wat } \\
\text { use crops } \\
\text { Application } \\
\text { rate, in } \\
\text { feet }\end{array}$ & $\begin{array}{l}\text { er } \\
\end{array}$ & $\begin{array}{l}\text { Pumpage, } \\
\text { in acre- } \\
\text { feet }\end{array}$ \\
\hline $19 N / 27 E-S E$ & 0.12 & 7.31 & 1.53 & 0 & 2.20 & 86 & 3.11 & 982 & 3,200 \\
\hline $19 N / 28 E-N E$ & .13 & 7.35 & 1.51 & 0 & 2.18 & 0 & 3.09 & 28 & 90 \\
\hline $19 \mathrm{~N} / 28 \mathrm{E}-\mathrm{NW}$ & .13 & 7.32 & 1.51 & 0 & 2.18 & 0 & 3.09 & 529 & 1,600 \\
\hline $19 \mathrm{~N} / 28 \mathrm{E}-\mathrm{SW}$ & .13 & 7.41 & 1.51 & 0 & 2.18 & 59 & 3.08 & 353 & 1,200 \\
\hline $19 \mathrm{~N} / 28 \mathrm{E}-\mathrm{SE}$ & .14 & 7.39 & 1.48 & 0 & 2.15 & 430 & 3.06 & 53 & 1,100 \\
\hline $19 N / 29 E-N E$ & .19 & 7.30 & 1.38 & 0 & 2.05 & 2,056 & 2.96 & 77 & 4,500 \\
\hline $19 \mathrm{~N} / 29 \mathrm{E}-\mathrm{NW}$ & .17 & 7.33 & 1.42 & 0 & 2.09 & 220 & 3.00 & 117 & 820 \\
\hline $19 N / 29 E-S E$ & .18 & 7.27 & 1.40 & 0 & 2.07 & 1,382 & 2.98 & 474 & 4,800 \\
\hline $19 N / 30 E-N E$ & .19 & 7.64 & 1.36 & 0 & 2.03 & 862 & 2.94 & 44 & 2,400 \\
\hline $19 N / 30 E-N W$ & .19 & 7.44 & 1.37 & 0 & 2.04 & 1,771 & 2.95 & 159 & 4,100 \\
\hline $19 N / 30 E-S W$ & .19 & 7.37 & 1.37 & 0 & 2.05 & 1,438 & 2.95 & 507 & 4,500 \\
\hline $19 N / 30 E-S E$ & .20 & 7.54 & 1.34 & 388 & 2.01 & 1,430 & 2.92 & 7 & 3,400 \\
\hline $19 N / 31 E-N E$ & .18 & 8.18 & 1.35 & 775 & 2.02 & 0 & 2.93 & 28 & 1,300 \\
\hline $19 N / 31 E-N W$ & .18 & 7.86 & 1.37 & 365 & 2.04 & 0 & 2.95 & 0 & 500 \\
\hline $19 N / 31 E-S W$ & .17 & 7.64 & 1.40 & 379 & 2.07 & 1,800 & 2.98 & 87 & 4,600 \\
\hline $19 \mathrm{~N} / 31 \mathrm{E}-\mathrm{SE}$ & .17 & 7.86 & 1.39 & 442 & 2.06 & 1,040 & 2.97 & 400 & 4,300 \\
\hline $19 N / 32 E-N W$ & .18 & 8.37 & 1.34 & 929 & 2.01 & 260 & 2.91 & 116 & 2,800 \\
\hline $19 N / 32 E-S W$ & .17 & 8.14 & 1.37 & 125 & 2.04 & 910 & 2.95 & 37 & 2,600 \\
\hline 19N/32E-SE & .18 & 8.33 & 1.34 & 0 & 2.01 & 802 & 2.92 & 205 & 2,600 \\
\hline $19 N / 33 E-N W$ & .18 & 8.60 & 1.32 & 887 & 1.99 & 780 & 2.90 & 3,443 & 4,600 \\
\hline $19 \mathrm{~N} / 34 \mathrm{E}-\mathrm{NW}$ & .18 & 8.81 & 1.31 & 313 & 1.98 & 0 & 2.89 & 0 & 430 \\
\hline $19 \mathrm{~N} / 34 \mathrm{E}-\mathrm{SW}$ & .18 & 8.56 & 1.33 & 324 & 2.00 & 0 & 2.90 & 0 & 430 \\
\hline $19 \mathrm{~N} / 35 \mathrm{E}-\mathrm{NE}$ & .16 & 9.31 & 1.32 & 561 & 1.99 & 0 & 2.90 & 0 & 740 \\
\hline $19 \mathrm{~N} / 36 \mathrm{E}-\mathrm{NE}$ & .18 & 9.38 & 1.28 & 914 & 1.95 & 390 & 2.85 & 0 & 1,900 \\
\hline $19 N / 36 E-S W$ & .15 & 9.32 & 1.35 & 686 & 2.02 & 520 & 2.92 & 0 & 2,000 \\
\hline $19 N / 36 E-S E$ & .14 & 9.51 & 1.36 & 106 & 2.03 & 130 & 2.94 & 0 & 410 \\
\hline $20 \mathrm{~N} / 25 \mathrm{E}-\mathrm{SW}$ & .09 & 6.89 & 1.62 & 4 & 2.30 & 744 & 3.20 & 1,166 & 5,400 \\
\hline $20 \mathrm{~N} / 26 \mathrm{E}-\mathrm{SE}$ & .12 & 6.68 & 1.57 & 18 & 2.24 & 452 & 3.15 & 455 & 2,500 \\
\hline $20 \mathrm{~N} / 27 \mathrm{E}-\mathrm{SE}$ & .11 & 6.99 & 1.57 & 0 & 2.24 & 38 & 3.15 & 261 & 910 \\
\hline $20 N / 29 E-N E$ & .18 & 7.37 & 1.40 & 0 & 2.07 & 514 & 2.98 & 80 & 1,400 \\
\hline $20 \mathrm{~N} / 29 \mathrm{E}-\mathrm{NW}$ & .12 & 7.24 & 1.54 & 0 & 2.21 & 296 & 3.12 & 87 & 930 \\
\hline $20 \mathrm{~N} / 29 \mathrm{E}-\mathrm{SE}$ & .18 & 7.34 & 1.40 & 251 & 2.07 & 780 & 2.98 & 217 & 2,600 \\
\hline $20 \mathrm{~N} / 30 \mathrm{E}-\mathrm{NE}$ & .19 & 7.79 & 1.35 & 154 & 2.02 & 390 & 2.93 & 112 & 1,500 \\
\hline $20 \mathrm{~N} / 30 \mathrm{E}-\mathrm{SW}$ & .19 & 7.53 & 1.37 & 512 & 2.04 & 260 & 2.94 & 98 & 1,800 \\
\hline 20N/30E-SE & .19 & 7.73 & 1.35 & 1,165 & 2.02 & 260 & 2.93 & 181 & 2,800 \\
\hline $20 \mathrm{~N} / 31 \mathrm{E}-\mathrm{NE}$ & .18 & 8.43 & 1.33 & 738 & 2.00 & 0 & 2.91 & 0 & 980 \\
\hline $20 \mathrm{~N} / 31 \mathrm{E}-\mathrm{NW}$ & .18 & 8.13 & 1.35 & 658 & 2.02 & 0 & 2.93 & 0 & 890 \\
\hline $20 \mathrm{~N} / 32 \mathrm{E}-\mathrm{NE}$ & .18 & 8.66 & 1.32 & 81 & 1.99 & 0 & 2.90 & 0 & 110 \\
\hline $20 \mathrm{~N} / 32 \mathrm{E}-\mathrm{NW}$ & .18 & 8.53 & 1.33 & 241 & 2.00 & 0 & 2.91 & 0 & 320 \\
\hline $20 \mathrm{~N} / 32 \mathrm{E}-\mathrm{SW}$ & .18 & 8.44 & 1.33 & 1,164 & 2.00 & 0 & 2.91 & 0 & 1,500 \\
\hline
\end{tabular}


TABLE 5. Ground-water pumpage, irrigated acreage, and application rates for 1985--continued

\begin{tabular}{|c|c|c|c|c|c|c|c|c|c|}
\hline $\begin{array}{l}\text { Quarter- } \\
\text { township }\end{array}$ & $\begin{array}{l}\text { Available } \\
\text { water cap- } \\
\text { acity, in } \\
\text { inches } \\
\text { per inch }\end{array}$ & $\begin{array}{l}\text { Precipi- } \\
\text { tation } \\
\text { for water } \\
\text { year } 1985 \text {, } \\
\text { in inches }\end{array}$ & $\begin{array}{l}\text { Noncenter } \\
\text { small gI } \\
\text { Applicatic } \\
\text { rate, in } \\
\text { feet }\end{array}$ & $\begin{array}{l}\text { pivot } \\
\text { rains } \\
\text { on }\end{array}$ & $\begin{array}{l}\text { Center piv } \\
\text { small grai } \\
\text { Application } \\
\text { rate, in } \\
\text { feet }\end{array}$ & $\begin{array}{l}\text { vot } \\
\text { ins }\end{array}$ & $\begin{array}{l}\text { High wate } \\
\text { use crops } \\
\text { Application } \\
\text { rate, in } \\
\text { feet }\end{array}$ & er- & $\begin{array}{l}\text { Pumpage, } \\
\text { in acre- } \\
\text { feet }\end{array}$ \\
\hline $20 N / 33 E-N E$ & 0.17 & 8.82 & 1.33 & 574 & 2.00 & 650 & 2.91 & 0 & 2,100 \\
\hline $20 N / 33 E-N W$ & .18 & 8.74 & 1.31 & 1,071 & 1.99 & 0 & 2.89 & 0 & 1,400 \\
\hline 20N/33E-SE & .20 & 8.81 & 1.27 & 0 & 1.94 & 561 & 2.84 & 0 & 1,100 \\
\hline $20 N / 34 E-N E$ & .18 & 9.12 & 1.29 & 854 & 1.96 & 130 & 2.87 & 0 & 1,400 \\
\hline 20N/35E-NE & .17 & 9.36 & 1.30 & 401 & 1.97 & 390 & 2.88 & 0 & 1,300 \\
\hline $20 N / 35 E-N W$ & .18 & 9.26 & 1.28 & 211 & 1.95 & 0 & 2.86 & 0 & 270 \\
\hline $20 N / 35 E-S W$ & .18 & 9.23 & 1.29 & 129 & 1.96 & 780 & 2.86 & 0 & 1,700 \\
\hline $20 N / 35 E-S E$ & .18 & 9.30 & 1.28 & 69 & 1.95 & 910 & 2.86 & 0 & 1,900 \\
\hline $20 N / 36 E-N E$ & .17 & 9.50 & 1.29 & 30 & 1.96 & 0 & 2.87 & 0 & 40 \\
\hline $20 \mathrm{~N} / 36 \mathrm{E}-\mathrm{NW}$ & .16 & 9.43 & 1.32 & 757 & 1.99 & 180 & 2.90 & 0 & 1,400 \\
\hline $20 N / 36 E-S E$ & .18 & 9.36 & 1.28 & 343 & 1.95 & 130 & 2.86 & 0 & 690 \\
\hline $21 N / 24 E-S W$ & .16 & 7.03 & 1.46 & 0 & 2.13 & 0 & 3.04 & 107 & 330 \\
\hline $21 N / 24 E-S E$ & .17 & 6.92 & 1.45 & 0 & 2.12 & 164 & 3.02 & 0 & 350 \\
\hline $21 N / 26 E-S W$ & .16 & 6.35 & 1.50 & 0 & 2.17 & 22 & 3.08 & 174 & 580 \\
\hline $21 N / 27 E-N W$ & .11 & 6.37 & 1.61 & 0 & 2.28 & 0 & 3.19 & 102 & 330 \\
\hline $21 N / 28 E-N E$ & .11 & 6.94 & 1.58 & 38 & 2.25 & 423 & 3.16 & 219 & 1,700 \\
\hline $21 N / 28 E-N W$ & .11 & 6.71 & 1.59 & 28 & 2.26 & 0 & 3.17 & 75 & 280 \\
\hline $21 N / 30 E-N E$ & .18 & 7.77 & 1.37 & 272 & 2.04 & 260 & 2.95 & 0 & 900 \\
\hline $21 N / 30 E-N W$ & .20 & 7.52 & 1.34 & 0 & 2.01 & 241 & 2.92 & 119 & 830 \\
\hline $21 N / 30 E-S E$ & .19 & 7.81 & 1.35 & 0 & 2.02 & 397 & 2.93 & 261 & 1,600 \\
\hline $21 N / 31 E-N E$ & .11 & 8.45 & 1.49 & 492 & 2.16 & 390 & 3.06 & 0 & 1,600 \\
\hline $21 N / 31 E-N W$ & .11 & 8.14 & 1.51 & 254 & 2.18 & 390 & 3.08 & 0 & 1,200 \\
\hline $21 N / 31 E-S W$ & .19 & 8.19 & 1.33 & 1,232 & 2.00 & 520 & 2.90 & 18 & 2,700 \\
\hline $21 \mathrm{~N} / 31 \mathrm{E}-\mathrm{SE}$ & .20 & 8.48 & 1.29 & 2,348 & 1.96 & 780 & 2.86 & 0 & 4,600 \\
\hline $21 N / 32 E-N W$ & .11 & 8.59 & 1.48 & 36 & 2.15 & 0 & 3.06 & 0 & 50 \\
\hline $21 N / 32 E-S W$ & .19 & 8.60 & 1.30 & 2,041 & 1.97 & 260 & 2.88 & 0 & 3,200 \\
\hline 21N/32E-SE & .20 & 8.67 & 1.27 & 127 & 1.95 & 910 & 2.85 & 0 & 1,900 \\
\hline $21 N / 33 E-N E$ & .16 & 8.73 & 1.36 & 267 & 2.03 & 70 & 2.94 & 0 & 510 \\
\hline $21 N / 33 E-N W$ & .11 & 8.63 & 1.48 & 162 & 2.15 & 130 & 3.05 & 0 & 520 \\
\hline $21 N / 33 E-S W$ & .20 & 8.69 & 1.27 & 769 & 1.94 & 0 & 2.85 & 0 & 980 \\
\hline $21 N / 34 E-S W$ & .20 & 8.95 & 1.26 & 1,492 & 1.93 & 0 & 2.84 & 0 & 1,900 \\
\hline $21 N / 34 E-S E$ & .20 & 9.16 & 1.25 & 824 & 1.92 & 0 & 2.82 & 0 & 1,000 \\
\hline $21 N / 35 E-N W$ & .20 & 9.60 & 1.22 & 917 & 1.89 & 0 & 2.80 & 0 & 1,100 \\
\hline $21 N / 36 E-S W$ & .20 & 9.67 & 1.21 & 141 & 1.88 & 0 & 2.79 & 0 & 170 \\
\hline $21 N / 36 E-S E$ & .20 & 9.81 & 1.21 & 168 & 1.88 & 0 & 2.78 & 0 & 200 \\
\hline $21 N / 39 E-N W$ & .17 & 11.01 & 1.20 & 183 & 1.87 & 0 & 2.78 & 0 & 220 \\
\hline $22 N / 26 E-S E$ & .11 & 6.36 & 1.61 & 14 & 2.28 & 0 & 3.19 & 742 & 2,400 \\
\hline 22N/27E-SW & .13 & 6.41 & 1.57 & 18 & 2.24 & 0 & 3.14 & 399 & 1,300 \\
\hline $22 N / 27 E-S E$ & .11 & 6.53 & 1.60 & 0 & 2.27 & 132 & 3.18 & 59 & 490 \\
\hline $22 N / 28 E-N E$ & .16 & 6.98 & 1.46 & 73 & 2.14 & 200 & 3.04 & 100 & 840 \\
\hline
\end{tabular}


TABLE 5. Ground-water pumpage, irrigated acreage, and application rates for 1985--continued

\begin{tabular}{|c|c|c|c|c|c|c|c|c|c|}
\hline $\begin{array}{l}\text { Quarter- } \\
\text { township }\end{array}$ & $\begin{array}{l}\text { Available } \\
\text { water cap- } \\
\text { acity, in } \\
\text { inches } \\
\text { per inch }\end{array}$ & $\begin{array}{l}\text { Precipi- } \\
\text { tation } \\
\text { for water } \\
\text { year } 1985 \text {, } \\
\text { in inches }\end{array}$ & $\begin{array}{l}\text { Noncenter } \\
\text { small gr } \\
\text { Applicatior } \\
\text { rate, in } \\
\text { feet }\end{array}$ & $\begin{array}{l}\text { pivot } \\
\text { cains } \\
\text { Acres }\end{array}$ & $\begin{array}{l}\text { Center pi } \\
\text { small gra } \\
\text { Application } \\
\text { rate, in } \\
\text { feet }\end{array}$ & $\begin{array}{l}\text { vot } \\
\text { ins }\end{array}$ & $\begin{array}{l}\text { High wate } \\
\text { use crops } \\
\text { Application } \\
\text { rate, in } \\
\text { feet }\end{array}$ & er- & $\begin{array}{l}\text { Pumpage, } \\
\text { in acre- } \\
\text { feet }\end{array}$ \\
\hline 22N/28E-NW & 0.17 & 6.77 & 1.46 & 0 & 2.13 & 256 & 3.03 & 0 & 550 \\
\hline $22 N / 28 E-S W$ & .15 & 6.73 & 1.50 & 0 & 2.17 & 500 & 3.08 & 76 & 1,300 \\
\hline $22 N / 28 E-S E$ & .15 & 6.95 & 1.49 & 95 & 2.16 & 716 & 3.07 & 51 & 1,900 \\
\hline $22 N / 29 E-N E$ & .15 & 7.29 & 1.47 & 191 & 2.14 & 0 & 3.05 & 108 & 610 \\
\hline $22 N / 29 E-N W$ & .18 & 7.13 & 1.41 & 22 & 2.08 & 0 & 2.99 & 82 & 280 \\
\hline $22 \mathrm{~N} / 30 \mathrm{E}-\mathrm{NE}$ & .17 & 7.79 & 1.39 & 401 & 2.06 & 0 & 2.97 & 25 & 630 \\
\hline $22 \mathrm{~N} / 30 \mathrm{E}-\mathrm{NW}$ & .18 & 7.53 & 1.39 & 36 & 2.06 & 0 & 2.97 & 0 & 50 \\
\hline $22 \mathrm{~N} / 30 \mathrm{E}-\mathrm{SE}$ & .20 & 7.72 & 1.33 & 0 & 2.00 & 1,100 & 2.91 & 138 & 2,600 \\
\hline $22 N / 31 E-N E$ & .20 & 8.55 & 1.28 & 151 & 1.95 & 130 & 2.86 & 0 & 450 \\
\hline $22 N / 31 E-S E$ & .15 & 8.44 & 1.40 & 0 & 2.07 & 635 & 2.98 & 0 & 1,300 \\
\hline $22 N / 32 E-S W$ & .11 & 8.62 & 1.48 & 160 & 2.15 & 0 & 3.05 & 0 & 240 \\
\hline $22 N / 33 E-N W$ & .15 & 8.76 & 1.38 & 219 & 2.05 & 0 & 2.96 & 0 & 300 \\
\hline $22 N / 33 E-S W$ & .20 & 8,66 & 1.28 & 653 & 1.95 & 520 & 2.85 & 0 & 1,900 \\
\hline $22 \mathrm{~N} / 33 \mathrm{E}-\mathrm{SE}$ & .20 & 8.78 & 1.27 & 236 & 1.94 & 260 & 2.85 & 0 & 800 \\
\hline $22 \mathrm{~N} / 34 \mathrm{E}-\mathrm{SE}$ & .13 & 9.47 & 1.38 & 1,726 & 2.05 & 0 & 2.96 & 0 & 2,400 \\
\hline $22 N / 35 E-S E$ & .20 & 10.26 & 1.18 & 50 & 1.85 & 0 & 2.76 & 73 & 260 \\
\hline $23 N / 27 E-N E$ & .20 & 6.75 & 1.39 & 0 & 2.06 & 0 & 2.97 & 25 & 80 \\
\hline $23 N / 27 E-S W$ & .16 & 6.60 & 1.49 & 49 & 2.16 & 0 & 3.07 & 0 & 70 \\
\hline $23 N / 27 E-S E$ & .12 & 6.67 & 1.57 & 7 & 2.24 & 0 & 3.15 & 47 & 160 \\
\hline $23 \mathrm{~N} / 28 \mathrm{E}-\mathrm{SE}$ & .19 & 7.01 & 1.40 & 0 & 2.07 & 1,157 & 2.97 & 17 & 2,400 \\
\hline $23 N / 29 E-N E$ & 20 & 7.39 & $=1.35$ & 0 & 2.02 & 793 & 2.93 & 0 & 1600 . \\
\hline $23 N / 29 E-N W$ & .20 & 7.23 & 1.36 & 0 & 2.03 & 592 & 2.94 & 0 & 1,200 \\
\hline $23 \mathrm{~N} / 29 \mathrm{E}-\mathrm{SE}$ & .19 & 7.32 & 1.38 & 0 & 2.05 & 330 & 2.96 & 40 & 790 \\
\hline $23 \mathrm{~N} / 30 \mathrm{E}-\mathrm{NE}$ & .14 & 7.80 & 1.46 & 149 & 2.13 & 0 & 3.04 & 43 & 350 \\
\hline $23 N / 30 E-S W$ & .18 & 7.60 & 1.38 & 82 & 2.05 & 0 & 2.96 & 0 & 180 \\
\hline $23 N / 30 E-S E$ & .10 & 7.84 & 1.55 & 96 & 2.22 & 0 & 3.12 & 18 & 210 \\
\hline $23 \mathrm{~N} / 31 \mathrm{E}-\mathrm{NE}$ & .20 & 8.46 & 1.29 & 453 & 1.96 & 455 & 2.87 & 0 & 1,500 \\
\hline $23 N / 31 E-S W$ & .20 & 8.23 & 1.30 & 502 & 1.97 & 130 & 2.88 & 0 & 910 \\
\hline $23 N / 31 E-S E$ & .20 & 8.57 & 1.28 & 29 & 1.95 & 520 & 2.86 & 0 & 1,100 \\
\hline $23 N / 32 E-N E$ & .16 & 8.77 & 1.36 & 952 & 2.03 & 1,800 & 2.94 & 0 & 4,900 \\
\hline $23 N / 32 E-N W$ & .20 & 8.66 & 1.28 & 1,931 & 1.95 & 640 & 2.85 & 0 & 3,700 \\
\hline $23 N / 32 E-S W$ & .20 & 8.66 & 1.28 & 642 & 1.95 & 0 & 2.85 & 0 & 820 \\
\hline $23 N / 33 E-N E$ & .20 & 9.44 & 1.23 & 2,129 & 1.90 & 130 & 2.81 & 0 & 2,900 \\
\hline $23 N / 33 E-N W$ & .20 & 9.08 & 1.25 & 978 & 1.92 & 260 & 2.83 & 0 & 1,700 \\
\hline $23 N / 34 E-S W$ & .11 & 9.49 & 1.42 & 28 & 2.09 & 130 & 3.00 & 0 & 310 \\
\hline $23 N / 36 E-S E$ & .20 & 10.60 & 1.16 & 99 & 1.83 & 0 & 2.74 & 101 & 390 \\
\hline $23 N / 38 E-S E$ & .18 & 11.14 & 1.17 & 92 & 1.84 & 0 & 2.75 & 271 & 850 \\
\hline $24 N / 29 E-N E$ & .17 & 7.29 & 1.42 & 7 & 2.09 & 2,214 & 3.00 & 128 & 5,000 \\
\hline $24 N / 31 E-S E$ & .20 & 8.28 & 1.30 & 608 & 1.97 & 390 & 2.88 & 0 & 1,600 \\
\hline $24 N / 32 E-N E$ & .18 & 8.78 & 1.31 & 3,140 & 1.98 & 760 & 2.89 & 0 & 5,600 \\
\hline
\end{tabular}


TABLE 5. Ground-water pumpage, Irrigated acreage, and application rates for 1985--continued

\begin{tabular}{|c|c|c|c|c|c|c|c|c|c|}
\hline $\begin{array}{l}\text { Quarter- } \\
\text { township }\end{array}$ & $\begin{array}{l}\text { Available } \\
\text { water cap- } \\
\text { acity, in } \\
\text { inches } \\
\text { per inch }\end{array}$ & $\begin{array}{l}\text { Precipi- } \\
\text { tation } \\
\text { for water } \\
\text { year } 1985, \\
\text { in inches }\end{array}$ & $\begin{array}{l}\text { Noncenter } \\
\text { small gr } \\
\text { Applicatio } \\
\text { rate, in } \\
\text { feet }\end{array}$ & $\begin{array}{l}\text { pivot } \\
\text { ains } \\
\text { Acres }\end{array}$ & $\begin{array}{l}\text { Center piv } \\
\text { small grai } \\
\text { Application } \\
\text { rate, in } \\
\text { feet }\end{array}$ & $\begin{array}{l}\text { vot } \\
\text { ins }\end{array}$ & $\begin{array}{l}\text { High wate } \\
\text { use crops } \\
\text { Application } \\
\text { rate, in } \\
\text { feet }\end{array}$ & $\mathrm{sr}^{-}$ & $\begin{array}{l}\text { Pumpage, } \\
\text { in acre- } \\
\text { feet }\end{array}$ \\
\hline $24 \mathrm{~N} / 32 \mathrm{E}-\mathrm{SW}$ & 0.20 & 8.58 & 1.28 & 926 & 1.95 & 400 & 2.86 & 0 & 2,000 \\
\hline $24 \mathrm{~N} / 32 \mathrm{E}-\mathrm{SE}$ & .16 & 8.80 & 1.36 & 1,574 & 2.03 & 0 & 2.93 & 0 & 2,100 \\
\hline $24 N / 33 E-S E$ & .20 & 9.56 & 1.22 & 115 & 1.89 & 759 & 2.80 & 0 & 1,600 \\
\hline $24 N / 34 E-S W$ & .20 & 9.76 & 1.21 & 314 & 1.88 & 893 & 2.79 & 0 & 2,100 \\
\hline $24 N / 36 E-N E$ & .16 & 10.72 & 1.24 & 116 & 1.91 & 0 & 2.82 & 54 & 300 \\
\hline $25 N / 28 E-N E$ & .13 & 7.19 & 1.52 & 0 & 2.19 & 670 & 3.10 & 51 & 1,600 \\
\hline $25 N / 28 E-S E$ & .14 & 7.19 & 1.50 & 2 & 2.17 & 1,116 & 3.07 & 188 & 3,100 \\
\hline $25 N / 29 E-N W$ & .16 & 7.11 & 1.46 & 74 & 2.13 & 80 & 3.03 & 0 & 280 \\
\hline $25 N / 29 E-S E$ & .13 & 7.15 & 1.52 & 0 & 2.19 & 818 & 3.10 & 41 & 1,900 \\
\hline $25 N / 30 E-N W$ & .20 & 7.19 & 1.36 & 29 & 2.03 & 260 & 2.94 & 122 & 930 \\
\hline $25 \mathrm{~N} / 31 \mathrm{E}-\mathrm{NW}$ & .20 & 7.95 & 1.32 & 188 & 1.99 & 0 & 2.90 & 47 & 390 \\
\hline $25 N / 32 E-S E$ & .20 & 8.84 & 1.26 & 587 & 1.93 & 520 & 2.84 & 0 & 1,700 \\
\hline $25 N / 33 E-N W$ & .20 & 9.11 & 1.25 & 0 & 1.92 & 208 & 2.83 & 0 & 400 \\
\hline $25 N / 33 E-S W$ & .20 & 9.16 & 1.25 & 729 & 1.92 & 650 & 2.82 & 0 & 2,200 \\
\hline $25 N / 33 E-S E$ & .20 & 9.48 & 1.23 & 871 & 1.90 & 0 & 2.80 & 0 & 1,100 \\
\hline $25 N / 34 E-N E$ & .20 & 9.96 & 1.20 & 183 & 1.87 & 0 & 2.78 & 53 & 370 \\
\hline $25 N / 34 E-N W$ & .20 & 9.67 & 1.21 & 19 & 1.88 & 0 & 2.79 & 0 & 20 \\
\hline $25 N / 34 E-S W$ & .19 & 9.74 & 1.23 & 68 & 1.90 & 0 & 2.81 & 0 & 80 \\
\hline $25 N / 35 E-S W$ & .19 & 10.26 & 1.20 & 0 & 1.87 & 0 & 2.78 & 132 & 370 \\
\hline $25 N / 36 E-S W$ & .18 & 10.73 & 1.20 & 139 & 1.87 & 0 & 2.77 & 412 & 1,300 \\
\hline $25 N / 36 E-S E$ & .18 & 10.83 & 1.19 & 0 & 1.86 & 0 & 2.77 & 106 & 290 \\
\hline $26 \mathrm{~N} / 29 \mathrm{E}-\mathrm{NW}$ & .20 & 7.32 & 1.36 & 9 & 2.03 & 0 & 2.93 & 36 & 120 \\
\hline $26 \mathrm{~N} / 31 \mathrm{E}-\mathrm{SW}$ & .20 & 8.06 & 1.31 & 158 & 1.98 & 0 & 2.89 & 0 & 210 \\
\hline $26 N / 32 E-N E$ & .20 & 9.18 & 1.24 & 2 & 1.91 & 320 & 2.82 & 0 & 610 \\
\hline $26 N / 32 E-N W$ & .15 & 9.00 & 1.37 & 0 & 2.04 & 187 & 2.94 & 0 & 380 \\
\hline $26 N / 33 E-N W$ & .20 & 9.18 & 1.24 & 48 & 1.91 & 0 & 2.82 & 0 & 60 \\
\hline $26 \mathrm{~N} / 33 \mathrm{E}-\mathrm{SW}$ & .20 & 9.16 & 1.25 & 983 & 1.92 & 0 & 2.82 & 0 & 1,200 \\
\hline 26N/33E-SE & .20 & 9.26 & 1.24 & 444 & 1.91 & 0 & 2.82 & 0 & 550 \\
\hline $27 N / 32 E-S W$ & .20 & 8.93 & 1.26 & 615 & 1.93 & 438 & 2.84 & 0 & 1,600 \\
\hline 28N/30E-NE & .15 & 8.06 & 1.42 & 0 & 2.09 & 0 & 3.00 & 49 & 150 \\
\hline $28 \mathrm{~N} / 30 \mathrm{E}-\mathrm{NW}$ & .15 & 8.04 & 1.42 & 0 & 2.09 & 0 & 3.00 & 70 & 210 \\
\hline
\end{tabular}




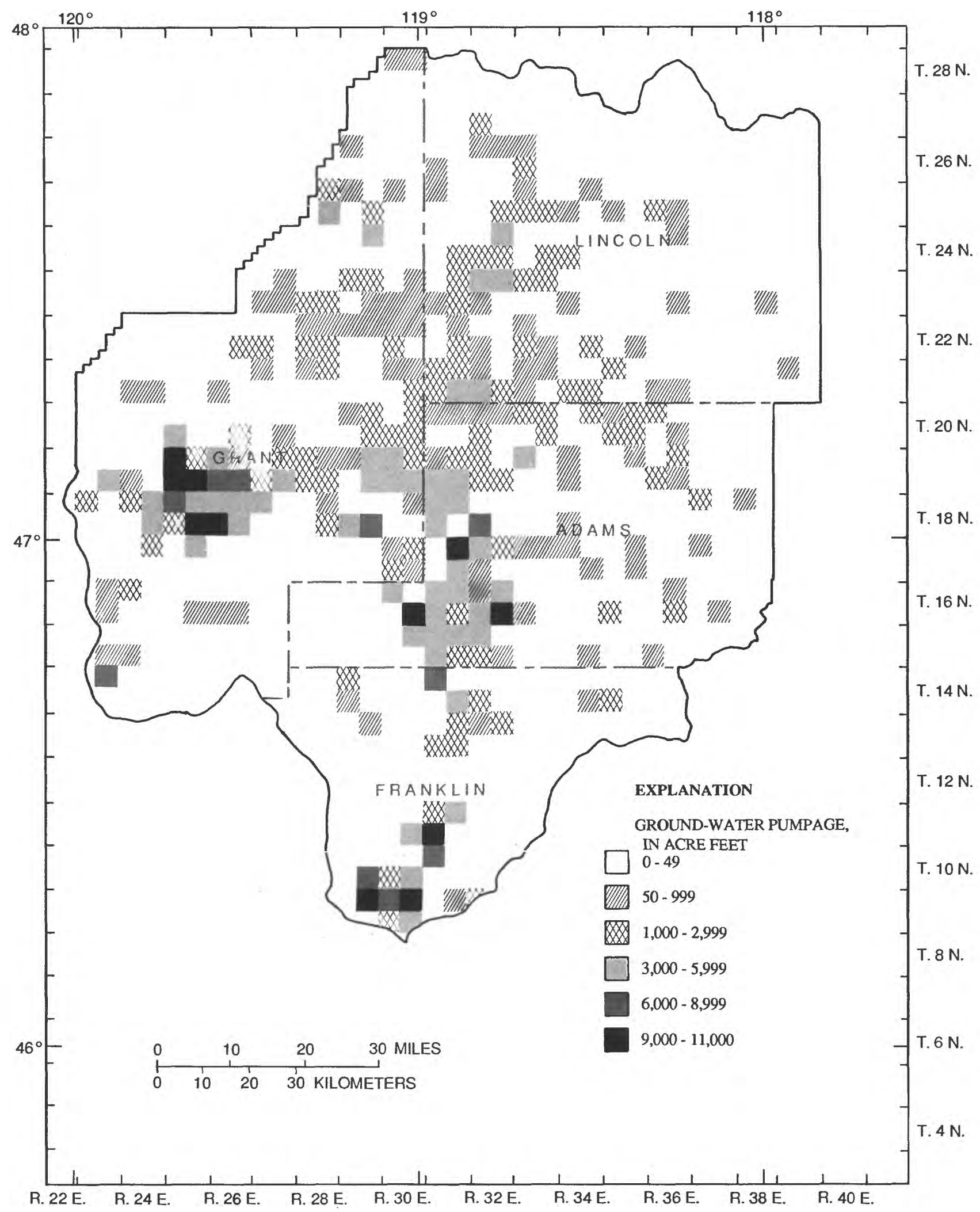

Figure 11.--Pumpage, by quarter-township, for 1985. 

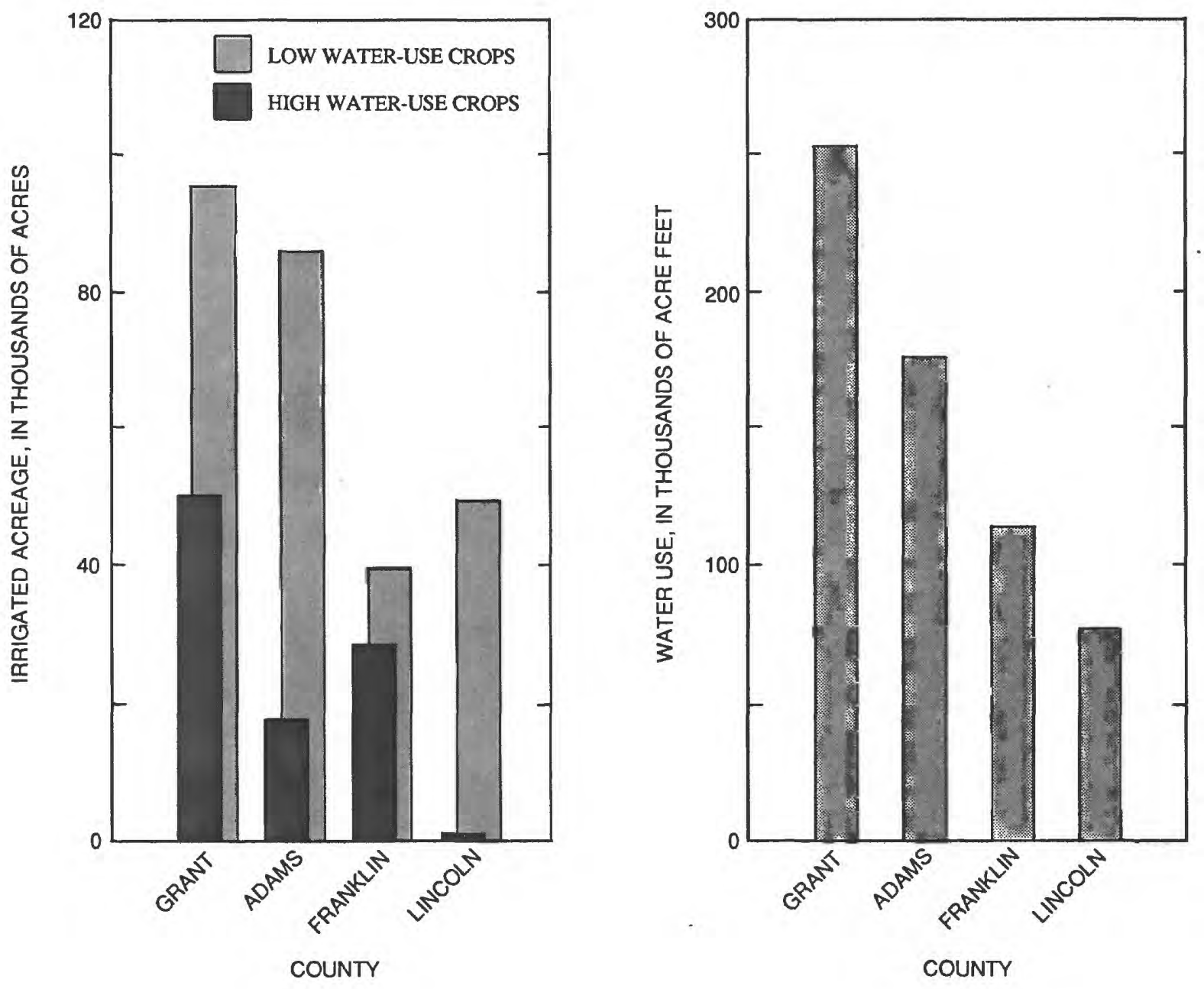

Figure 12.--Summary of irrigated acreage and water use, by county, for 1985. 
TABLE 6.--Ground-water pumpage and irrigated acreage by county

\begin{tabular}{|c|c|c|c|c|}
\hline \multirow[b]{2}{*}{ County } & \multicolumn{3}{|c|}{ Irrigated acres } & \multirow[b]{2}{*}{$\begin{array}{l}\text { Pumpage, in } \\
\text { acre feet }\end{array}$} \\
\hline & $\begin{array}{l}\text { Small } \\
\text { grains }\end{array}$ & $\begin{array}{l}\text { High water- } \\
\text { use crops }\end{array}$ & $\begin{array}{c}\text { Total } \\
\text { (rounded) }\end{array}$ & \\
\hline Franklin & 10,866 & 29,166 & 40,030 & 113,380 \\
\hline Adams & 67,907 & 18,092 & 86,000 & 175,810 \\
\hline Grant & 45,003 & 50,523 & 95,530 & 253,400 \\
\hline Lincoln & 48,895 & 1,267 & 50,160 & 76,710 \\
\hline Total & 172,671 & 99,048 & 271,720 & 619,300 \\
\hline
\end{tabular}

\section{Accuracy}

The accuracy of this approach at predicting pumpage was assessed using 28 sites selected randomly from the 95 sites that were used as water-application-rate sample sites for 1 or more years. Actual acres for each of those sites were compared to Landsat-mapped acres for each for the 1985 growing season. Actual pumpage, as computed by the measured-pump-efficiency/power-consumption approach or the time-of-operation times measured-flow approach (described in the section "Collection and Calculation of Pumpage at Sample Sites"), was compared with the pumpage predicted by regression-predicted application rate times Landsat-mapped acres for each site. Data for each of the 28 sites, including total pumpage for all sites, are listed in table 7. Although it is apparent that the pumpage predicted for an individual site can be considerably different from the observed pumpage, the total predicted pumpage for the 28 sites was within 4 percent of the total observed pumpage.

\section{Discussion}

Principal inaccuracies in estimating pumpage using Landsat imagery are caused by Landsat identification errors, unexplained variation in water-application rates (caused to some degree by differences in farm practice), and the difficulty in assigning irrigated acreage and pumpage to individual wells.

The most significant problems encountered in the Landsat analysis are errors in distinguishing between dryland and irrigated small grains and timing the data collection to coincide with desired crop growth stages. The range in precipitation over the study area causes uncertainty in distinguishing dryland and irrigated small grains, especially in eastern Lincoln and Adams Counties, where precipitation is greatest. This would be particularly troublesome in a relatively wet year. The TM analysis done in the northern part of the study area showed significantly better accuracy in distinguishing irrigated from nonirrigated small grains than was achieved using MSS. The addition of a second TM image from late July or August would add the temporal difference in crop growth stage used in the MSS ratioing approach and may improve the accuracy of the TM analysis, particularly in identifying miscellaneous and high water-use crops.

For these reasons, the Landsat analysis approach best suited to the Columbia Plateau would appear to be a two-date TM analysis. Such an analysis, combined with the regression approach for estimating water-application rates, should yield accurate estimations of pumpage and would provide digital maps of irrigated croplands. The Landsat analysis also could be extended to map general land use prior to focusing on the ground-water-irrigated lands if such information were of interest. 
TABLE 7.--Observed and predicted application rates, acres, and pumpage for 28 test sites

[A, alfalfa, P, potatoes; C, corn; WW, center pivot small grains; WL, noncenter pivot small grains; HI, high water use; F, fallow; and HW, both high water use and center pivot small grains]

\begin{tabular}{|c|c|c|c|c|c|c|c|c|}
\hline \multirow[b]{3}{*}{ Site } & \multicolumn{2}{|c|}{ Crops } & \multirow{2}{*}{\multicolumn{2}{|c|}{$\begin{array}{c}\text { Application rates, } \\
\text { in feet }\end{array}$}} & \multicolumn{2}{|c|}{ Acres } & \multirow{2}{*}{\multicolumn{2}{|c|}{$\begin{array}{c}\text { Pumpage, in acre } \\
\text { feet }\end{array}$}} \\
\hline & \multirow[b]{2}{*}{ Observed } & \multirow{2}{*}{$\begin{array}{l}\text { Landsat } \\
\text { mapped }\end{array}$} & & & \multirow[b]{2}{*}{ Observed } & \multirow{2}{*}{$\begin{array}{l}\text { Landsat } \\
\text { mapped }\end{array}$} & & \\
\hline & & & Observed & Predicted & & & Observed & Landsat \\
\hline 1 & A & $\mathrm{HI}$ & 3.49 & 3.23 & 140 & 140 & 488 & 452 \\
\hline 2 & A & HI & 2.91 & 3.23 & 178 & 193 & 518 & 623 \\
\hline 3 & P & $W W$ & 3.94 & 2.32 & 126 & 87 & 496 & 201 \\
\hline 4 & C & HI & 3.61 & 3.20 & 126 & 148 & 455 & 473 \\
\hline 5 & C & F & 2.90 & ${ }^{1} 3.20$ & 126 & 0 & 365 & 0 \\
\hline 6 & C & $\mathrm{HI}$ & 3.25 & 3.13 & 150 & 162 & 488 & 507 \\
\hline 7 & WW & $W W$ & 2.29 & 2.23 & 126 & 142 & 288 & 316 \\
\hline 8 & $P$ & $\mathrm{HI}$ & 2.98 & 3.21 & 140 & 97 & 417 & 311 \\
\hline 9 & A & HI & 2.83 & 3.21 & 126 & 130 & 357 & 417 \\
\hline 10 & WW & WW & 2.21 & 2.31 & 126 & 137 & 279 & 316 \\
\hline 11 & A & $\mathrm{HI}$ & 3.29 & 3.21 & 126 & 130 & 414 & 417 \\
\hline 12 & c & $\mathrm{HI}$ & 3.41 & 3.21 & 126 & 130 & 430 & 417 \\
\hline 13 & $P$ & F & 2.50 & ${ }^{1} 3.21$ & 126 & 0 & 315 & 0 \\
\hline 14 & C & WW & 2.21 & 2.23 & 150 & 140 & 332 & 312 \\
\hline 15 & $P$ & HI & 3.25 & 3.14 & 63 & 120 & 205 & 376 \\
\hline 16 & P & $\mathrm{HI}$ & 3.54 & 3.22 & 126 & 130 & 446 & 418 \\
\hline 17 & C & $\mathrm{HI}$ & 3.21 & 3.20 & 130 & 130 & 417 & 416 \\
\hline 18 & $W_{L}$ & WL & 3.00 & 1.36 & 80 & 77 & 240 & 104 \\
\hline 19 & WW & $\mathrm{HW}^{2}$ & 1.45 & 22.36 & 480 & 170 & 696 & 401 \\
\hline 20 & WW & WW & 1.79 & 2.25 & 252 & 283 & 451 & 636 \\
\hline 21 & WW & WW & 1.62 & 2.04 & 126 & 155 & 204 & 316 \\
\hline 22 & WW & WW & 1.82 & 2.01 & 85 & 81 & 155 & 162 \\
\hline 23 & A & $\mathrm{HI}$ & 2.31 & 2.92 & 110 & 95 & 254 & 277 \\
\hline 24 & WW & WW & 1.47 & 2.01 & 160 & 160 & 235 & 321 \\
\hline 25 & WL & WL & 0.95 & 1.48 & 120 & 32 & 114 & 47 \\
\hline 26 & WW & WW & 1.06 & 1.94 & 260 & 261 & 276 & 506 \\
\hline 27 & WW & WW & 2.00 & 2.09 & 1,200 & 1,172 & 2,395 & 2,449 \\
\hline \multirow[t]{2}{*}{28} & WW & WW & 2.10 & 2.19 & 556 & 594 & 1,168 & 1,300 \\
\hline & & & & & & TOTAL & 12,898 & 12.491 \\
\hline
\end{tabular}

${ }^{1}$ High water-use rate, 1isted for comparison.

${ }^{2}$ Combination of crops mapped; rate is average weighted by acres of each.

Temporal changes in irrigation practices and land use indicate that this type of study would be of maximum value if repeated every several years. The results would update estimates of the application rates and distribution of ground-water pumpage on the Columbia Plateau and improve understanding of irrigation water-use practices. 


\section{SUMMARY}

This report presents a method for estimating ground-water pumpage for irrigation. The procedure combines annual water-application rates calculated by a regression model with irrigated areas mapped using Landsat imagery. The study area consisted of Grant, Lincoln, Adams, and Franklin Counties on the Columbia Plateau in eastern Washington.

Analysis results using data from Landsat's MSS and TM scanners were compared. Four different data manipulation approaches using MSS data were compared, and the best of those approaches was compared with TM analysis. All four MSS approaches used data from two dates, May 21 and August 25, 1985. The TM analysis used data from one date, June 22, 1985. TM analysis resulted in a 6-percent improvement over the best MSS approach when comparing accuracy of identification by crop water-use category.

Ground-water-irrigated crops were mapped for the study area for 1985 using the best MSS approach. Groundwater-irrigated crops also were mapped for about two-thirds of the study area using TM. Where MSS and TM mapping coincided, the TM results were used in the subsequent calculation of pumpage.

A total of 576 annual water-application rates associated with particular crops were calculated for the 1982 through 1985 growing seasons. Private landowners provided 305 of those samples, and U.S. Geological Survey personnel collected the rest. A regression equation was developed for estimating annual water-application rates as a function of crop type, annual precipitation, irrigation-system type, and available water capacity of the soil. Two additional independent variables were considered insignificant--annual potential evapotranspiration and total operating head of the irrigation system.

Ground-water pumpage for irrigation for 1985 was calculated by multiplying irrigated areas mapped by Landsat times annual water-application rates predicted by regression equation. Pumpage was summarized and plotted by quarter-township, and total pumpage for the study area was estimated as 620,000 acre-feet.

An assessment of accuracy for estimating annual pumpage was made using 28 sites randomly selected from water-application rate sample sites monitored by this study. Although it was apparent that the pumpage predicted for an individual site can be considerably different from that observed, the total predicted pumpage for the 28 sites was within 4 percent of the total observed pumpage. 


\section{SELECTED REFERENCES}

Abotteen, R.A., 1977, Principal component greenness transformation in multitemporal agricultural Landsat data: Proceedings, 11th International Symposium on Remote Sensing of Environment, Environmental Research Institute of Michigan, Ann Arbor, p. 765-774.

Bauer, M.E., Cipra, J.E., Anuta, P.E., and Etheridge, J.A., 1979, Analysis of agricultural crops by computer classification of Landsat MSS data: Remote Sensing of Environment, v. 8, p. 75-92.

Bauer, H.H., and Vaccaro, J.J., 1986, Documentation of a deep percolation model for estimating ground-water recharge: U.S. Geological Survey Open-File Report 86-536, 180 p.

Cline, D.R., and Knadle, M.E., 1990, Ground-water pumpage from the Columbia Plateau regional aquifer system, Washington, 1984: U.S. Geological Survey Water-Resources Investigations Report 87-4135, 32 p.

Davis, John C., 1973, Statistics and data analysis in geology: Wiley and Sons, Inc., New York, NY, 543 p.

Donaldson, Wallace R., 1979, Washington climate for Grant, Kittitas, Klickitat, and Yakima Counties: Washington State University Agricultural Extension Service, EM4422, 84 p.

Draper, N.R., and Smith, H., 1966, Applied Regression Analysis: Wiley and Sons, Inc., New York, NY, 407 p.

Jensen, M.E., editor, 1973, Consumptive use of water and irrigation water requirements: American Society of Civil Engineers, Irrigation and Drainage Division, 215 p.

Jensen, M.E., Robb, D., and Franzoy, C.E., 1970, Scheduling irrigations using climate-crop-soil data: Journal of the Irrigation and Drainage Division, American Society of Civil Engineers, v. 96, no. IR1, March 1970, $14 \mathrm{p}$.

Lo, T.H.C., Scarpace, F.L., and Lillesand, T.M., 1986, Use of multitemporal spectral profiles in agricultural land-cover classification: Photogrammetric Engineering and Remote Sensing, v. 52, no. 4, p. 535-544.

Phillips, Earl L., 1965, Washington climate for Adams, Lincoln, Spokane, and Whitman Counties: Washington State University Agricultural Extension Service, EM 2545, 64 p.

Saxton, K.E., Johnson, H.P., and Shaw, R.H., 1974, Modeling evapotranspiration and soil moisture: American Society of Agricultural Engineers, Soil and Water Division, ASAE Paper No. 71-763b.

U.S. Department of Agriculture, 1967 [revised 1970], Irrigation water requirements: Soil Conservation Service Technical Release No. 21, Engineering Division, 88 p.

Zhicheng, Q., 1984, Theoretical analysis of ratios for multiband images: Proceedings of Fifth Asian Conference on Remote Sensing, Kathmandu, Nepal, p. 9-1 to 9-7. 